\title{
Polynuclear Cobalt Complexes as Catalysts for Light-Driven Water Oxidation: A Review of Recent Advances
}

\author{
Dmytro S. Nesterov*(D) and Oksana V. Nesterova *(D) \\ Centro de Química Estrutural, Instituto Superior Técnico, Universidade de Lisboa, Av. Rovisco Pais, \\ 1049-001 Lisboa, Portugal \\ * Correspondence: dmytro.nesterov@tecnico.ulisboa.pt (D.S.N.); oksana.nesterova@tecnico.ulisboa.pt (O.V.N.); \\ Tel.: +351-218-419-241 (O.V.N.)
}

Received: 5 November 2018; Accepted: 27 November 2018; Published: 2 December 2018

\begin{abstract}
Photochemical water oxidation, as a half-reaction of water splitting, represents a great challenge towards the construction of artificial photosynthetic systems. Complexes of first-row transition metals have attracted great attention in the last decade due to their pronounced catalytic efficiency in water oxidation, comparable to that exhibited by classical platinum-group metal complexes. Cobalt, being an abundant and relatively cheap metal, has rich coordination chemistry allowing construction of a wide range of polynuclear architectures for the catalytic purposes. This review covers recent advances in application of cobalt complexes as (pre)catalysts for water oxidation in the model catalytic system comprising $\left[\mathrm{Ru}(\mathrm{bpy})_{3}\right]^{2+}$ as a photosensitizer and $\mathrm{S}_{2} \mathrm{O}_{8}{ }^{2-}$ as a sacrificial electron acceptor. The catalytic parameters are summarized and discussed in view of the structures of the catalysts. Special attention is paid to the degradation of molecular catalysts under catalytic conditions and the experimental methods and techniques used to control their degradation as well as the leaching of cobalt ions.
\end{abstract}

Keywords: polynuclear cobalt complexes; water oxidation; artificial photosynthesis

\section{Introduction}

Currently, worldwide energy demand is satisfied mostly with fossil fuels, such as gas, oil, and coal [1,2]. Although these energy resources are rather easy to use, they contain a few principal drawbacks: limited stock, high consumption of $\mathrm{O}_{2}$ as well as high $\mathrm{CO}_{2}$ emission and, finally, high risk of environmental pollution. It is for these reasons that the search for highly efficient energy sources has been of high interest during the last decades. The use of sunlight, as an inexhaustible energy source with the ground level flux of ca. $1360 \mathrm{~W} \mathrm{~m}^{-2}$ [3], is an attractive alternative to fossil fuels. The chemical approach to sunlight energy utilization is to develop photo-driven processes able to replace the existing environmentally non-friendly ones. The photosynthesis of carbohydrates from $\mathrm{CO}_{2}$ and water, occurring in natural biosystems, represents a perfect model to be studied [4]. The energy for this process is provided by photosystem (PSI and PSII) protein complexes, and through the formation of ATP and NADPH under visible light exposure. In brief, (for recent reviews see [5-10]), upon irradiation, the photosensitizer (chlorophyll) in the PSII abstracts electrons from a water-oxidizing complex (WOC). The latter oxidizes water and releases $\mathrm{O}_{2}$ to close the catalytic cycle within the PSII system. The four-electron process of water oxidation, which also produces four protons, consumes significant energy and, at the same time, is potentially attractive for practical applications when protons are reduced to $\mathrm{H}_{2}$ [10-12].

While the existence of biological photosynthesis has been known for a long time [13], the principal details about the structure of the PSII and WOC were obtained only in 21st century [14,15]. The first 
single crystal X-ray structure analysis of the catalytically active PSII from cyanobacterium at $3.8 \AA$ resolution was accomplished in 2001, but the structure of the WOC was not resolved in detail [16]. Just few years later (in 2004 and 2005) a better set of data, collected at 3.5 and $3.0 \AA$ resolutions, allowed researchers to propose a cubane-like $\mathrm{Mn}_{3} \mathrm{CaO}_{4}$ structure of the WOC [17,18]. In 2011 the experimental results were improved by collecting the data at $1.9 \AA$ [19], revealing that the structure of the WOC contains four manganese atoms, where cubane fragment $\mathrm{Mn}_{3} \mathrm{CaO}_{4}$ is accompanied with the fourth $\mathrm{Mn}$ atom bridged to cubane with two oxygen atoms (Figure 1). The oxygen-evolving mechanism presumes stepwise oxidation of manganese atoms to $\mathrm{Mn}^{\mathrm{IV}}$ and/or $\mathrm{Mn}^{\mathrm{V}}$ with formation of high-valent metal-oxo species, which oxygen atoms "join" to release $\mathrm{O}_{2}$ molecules [5,20-22]. The role of redox-inactive calcium is still not fully clear $[5,23]$. Most probably, the calcium center acts as a Lewis acid and coordinates water molecules, thus assisting the mechanism [23,24]. Calcium could influence the redox potentials of the manganese cluster, as evidenced by the model studies [25-27]. Also, it was demonstrated that $\mathrm{Ca}^{2+}$ is required for the assembly of the oxygen-evolving center (OEC) $[23,28]$. The mechanism of action of the PSII has been the subject of numerous experimental and theoretical investigations (which are far from the final conclusion) and we would like to refer readers to the recent reviews on this topic $[5,6,8,9,15]$.
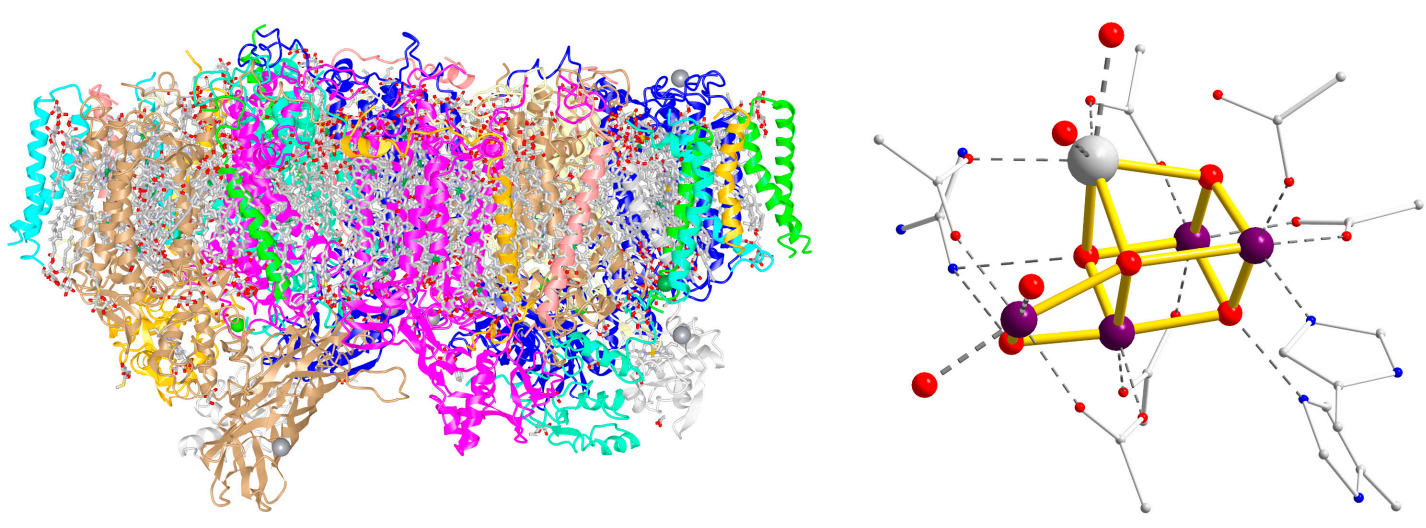

Figure 1. Overall structure (left) and $\mathrm{Mn}_{4} \mathrm{CaO}_{4}$ site (right) in PSII (PDB code 3WU2). Colour scheme: $\mathrm{Mn}$, violet; $\mathrm{Ca}$, grey; $\mathrm{O}$, red; $\mathrm{N}$, blue; $\mathrm{C}$, grey (small balls). $\mathrm{M}-\mathrm{O}-\mathrm{M}$ bonds are highlighted by yellow.

From the point of view of coordination chemistry, the complex bearing $\mathrm{Mn}_{3} \mathrm{CaO}_{4}$ or $\mathrm{Mn}_{4} \mathrm{CaO}_{4}$ core looks relatively simple. Cubane, $\mathrm{M}_{4}\left(\mu_{3}-\mathrm{O}\right)_{4}$, is the most widespread molecular structure type for tetranuclear coordination compounds [29] with more than 1000 examples in the Cambridge Structural Database (CSD) [30]. Discovery of the WOC structure of the PSII, inspired chemists to synthesize model coordination compounds having related polynuclear assemblies (biomimetic approach) and redox potentials [25-27]. The principal idea of this approach was to design well-defined molecular systems that allow for the studying of the mechanisms of action. An artificial water oxidation system comprises the same principal components as the natural one: photosensitizer, catalyst, and electron acceptor $[10,31]$. One of the most simple, efficient, and studied photosensitizers is $\left[\mathrm{Ru}(\mathrm{bpy})_{3}\right]^{2+}(\mathrm{bpy}=$ $2,2^{\prime}$-bipyridine) [10,32]. Absorption of a visible light photon with $\lambda=450 \mathrm{~nm}$ transfers this complex to an exited state which easily loses electron to produce $\left[\mathrm{Ru}(\mathrm{bpy})_{3}\right]^{3+}$, a strong oxidant. Sacrificial electron acceptor is required for this scheme of action. The most common known is persulfate, $\mathrm{S}_{2} \mathrm{O}_{8}{ }^{2-}[10,33]$. Finally, a buffer is required for keeping the $\mathrm{pH}$ value at the proper level. The overall catalytic system for the screening of the WOC activity is depicted in Scheme 1. A large series of metal complexes have been tested as WOCs using this scheme, mainly compounds of ruthenium and iridium [10,31,34]. However, the first-row transition metals, as the more abundant and less expensive ones, also represent a great interest form a practical point of view [35-38]. In this review we focus on the cobalt polynuclear complexes as the catalysts for light-driven water oxidation, with special attention to their stability under the studied catalytic conditions. 


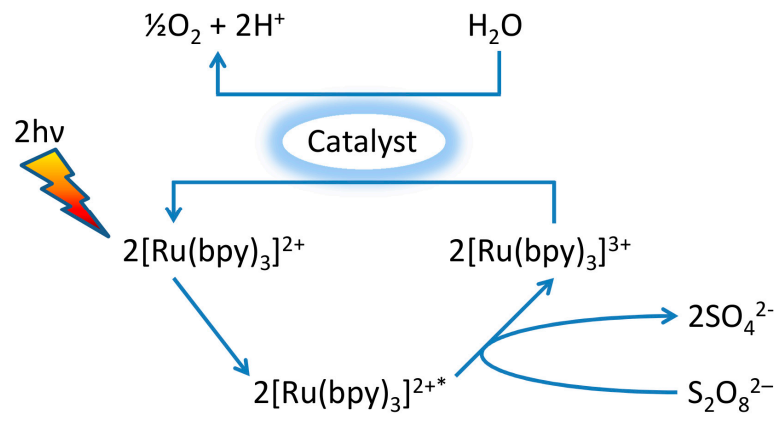

Scheme 1. General functioning mechanism of the light driven water oxidation system $\left[\mathrm{Ru}(\mathrm{bpy})_{3}\right]^{2+} /$ Catalyst $/ \mathrm{S}_{2} \mathrm{O}_{8}{ }^{2-}$.

Despite the impressive number of $\mathrm{H}_{2}$-evolving water splitting (reduction) cobalt catalysts [39], the field of cobalt-catalysed water oxidation has risen only during the last decade. The activity of simple cobalt compounds (salts and oxides) in the catalytic chemical water oxidation with $[\mathrm{Ru}(\mathrm{bpy})]^{3+}$ or other strong oxidants has been known for some time [10], but did not attract much attention until 2008, where Kanan and Nocera presented the Co-P electrocatalytic film for water oxidation formed in situ from aqueous $\mathrm{Co}^{2+}$ in phosphate buffer at neutral pH [40]. In 2009, Jiao and Frei reported the light driven system with the $\mathrm{Co}_{3} \mathrm{O}_{4}$ nanoparticles as a WOC, operating at mild conditions (room temperature and $\mathrm{pH}$ 5.8) [41]. The system $\left[\mathrm{Ru}(\mathrm{bpy})_{3}\right] \mathrm{Cl}_{2} / \mathrm{Co}_{3} \mathrm{O}_{4} / \mathrm{Na}_{2} \mathrm{~S}_{2} \mathrm{O}_{8}$ shows the TOF (turnover frequency, moles of product produced per mol of catalyst per a certain period of time) of more than $1000 \mathrm{~s}^{-1}$ per $\mathrm{Co}_{3} \mathrm{O}_{4}$ nanoparticle. For comparison, the TOF of the natural PSII is estimated at 100 to $400 \mathrm{~s}^{-1}$ level in live cells and $1000 \mathrm{~s}^{-1}$ in vitro [42]. Just one year after, in 2010, a study was published that highlighted a stable carbon-free WOC based on tetranuclear cobalt moiety $\left[\mathrm{Co}_{4}\left(\mathrm{H}_{2} \mathrm{O}\right)_{2}\left(\mathrm{PW}_{9} \mathrm{O}_{34}\right)_{2}\right]^{10-}$ for chemical water oxidation with $[\mathrm{Ru}(\mathrm{bpy})]^{3+}$, allowing the TOF of $5 \mathrm{~s}^{-1}$ and TON (turnover number, moles of product per mol of catalyst) of 78, and then (in 2011) for light-driven oxidation to reach the TON of $>220[43,44]$. Remarkably, in the same year, 2011, Stracke and Finke reported that under the conditions of electrocatalytic water oxidation, this compound releases $\mathrm{Co}^{2+}$ ions to form $\mathrm{CoO}_{x}$ as an active catalyst [45]. These reports caused considerable interest in the field but also demonstrated the complexity of the problem of clear identification of the true WOC.

\section{Mono- and Binuclear Cobalt Complexes}

The complex $\left[\mathrm{Co}\left(\mathrm{L}^{1}\right)\right]$ (1) (Figure 2) with Schiff base ligand $\mathrm{H}_{2} \mathrm{~L}^{1}$ ( $\mathrm{N}, \mathrm{N}^{\prime}$-bis(salicylidene) ethylenediamine, known also as "salen"), shows high TON and TOF values, as well as the quantum yield of $\mathrm{O}_{2}$, using $\left[\mathrm{Ru}(\mathrm{bpy})_{3}\right]\left(\mathrm{ClO}_{4}\right)_{2}$ as a photosensitizer (Table 1) [46]. When the $\mathrm{ClO}_{4}{ }^{-}$anion was replaced with $\mathrm{Cl}^{-}$or $\mathrm{SO}_{4}{ }^{2-}$ one the TON drops to ca. 780 and 190, respectively. Complex 1 retains its activity when $\left[\mathrm{Ru}(\mathrm{bpy})_{3}\right]\left(\mathrm{ClO}_{4}\right)_{3}$ was used as a terminal chemical oxidant, although showing lower catalytic parameters (Table 1). Further investigations disclosed that 1 was a pre-catalyst and its catalytic activity was associated to cobalt nanoparticles formed during the photocatalysis. According to ESI-MS (electrospray mass spectrometry) and DLS (dynamic light scattering) measurements, complex $\mathbf{1}$ was shown to be stable in the presence of the main components of the catalytic system, in the absence of light. However, after illumination the presence of nanoparticles of various sizes $(1-1000 \mathrm{~nm})$ were detected by the DLS method. Moreover, no signals from salen ligand were observed by ${ }^{1} \mathrm{H}$ NMR, suggesting its complete decomposition. The precipitate formed after the illumination was recovered and used again as a catalyst, showing somewhat lower water oxidation activity than 1 (40.9 and $54.6 \%$ of the yield of $\mathrm{O}_{2}$ based on $\mathrm{S}_{2} \mathrm{O}_{4}{ }^{2-}$, respectively). The cobalt nitrate was tested as WOC (31a, Table 1) under the same conditions as above, showing nearly the same TON as $\mathbf{1}$ as well as similar $\mathrm{O}_{2}$ accumulation kinetics [46]. Cobalt salts form $\mathrm{CoO}_{\mathrm{x}}$ nanoparticles in the $\left[\mathrm{Ru}(\mathrm{bpy})_{3}\right]^{2+} / \mathrm{S}_{2} \mathrm{O}_{8}{ }^{2-}$ water oxidation systems (31-33, Table 1), providing a non-direct proof for the instability of $\mathbf{1}$, which appears to be just a pre-catalyst. 
Table 1. Selected catalytic parameters for the catalysts 1-33 in oxidation of water using $\left[\mathrm{Ru}(\mathrm{bpy})_{3}\right]^{2+}$ as a photosensitizer and $\mathrm{S}_{2} \mathrm{O}_{8}{ }^{2-}$ as a sacrificial electron acceptor.

\begin{tabular}{|c|c|c|c|c|c|c|c|c|c|c|c|c|c|}
\hline $\mathbf{N}$ & Core & (Pre)catalyst & $\begin{array}{c}\mathrm{O}_{2} \\
\text { Evolution, } \\
\mu \mathrm{mol} / \mu \mathrm{M}\end{array}$ & TON $^{1}$ & $\begin{array}{c}\mathrm{TOF}^{2} \\
\mathrm{~s}^{-1}\end{array}$ & $\underset{\%}{\mathrm{QE}^{3},}$ & $\lambda^{4}, \mathrm{~nm}$ & Irradiation Source & $\mathrm{pH}$ & $\mathrm{NP}^{5}$ & Anion ${ }^{6}$ & $\begin{array}{c}{[\mathrm{cat}]_{0},} \\
\mu \mathrm{M}\end{array}$ & Ref. \\
\hline $1 \mathrm{a}$ & $\mathrm{Co}_{1}$ & {$\left[\mathrm{Co}^{\mathrm{II}}\left(\mathrm{L}^{1}\right)\right]$} & $13.7 / 1366$ & 854 & 6.4 & 38.6 & $>420$ & $\mathrm{LED}, 5.1 \mathrm{~mW} / \mathrm{cm}^{2}$ & 9 & + & $\mathrm{ClO}_{4}$ & 1.6 & [46] \\
\hline $1 b$ & $\mathrm{Co}_{1}$ & {$\left[\mathrm{Co}^{\mathrm{II}}\left(\mathrm{L}^{1}\right)\right]$} & n.d. ${ }^{7}$ & 194 & 2.0 & - & - & $\begin{array}{l}\text { Chemical oxidation with } \\
{\left[\mathrm{Ru}(\mathrm{bpy})_{3}\right]^{3+}}\end{array}$ & 9 & $\underset{7}{\text { n.d. }}$ & $\mathrm{ClO}_{4}$ & n.d. & [46] \\
\hline 2 & $\mathrm{Co}_{1}$ & {$\left[\mathrm{CO}^{\mathrm{II}}(\mathrm{TPPS})\right]$} & $12.2 / 1220$ & 122 & 0.17 & n.d. & $400-800$ & Xe lamp, $300 \mathrm{~W}$ & 11 & - & $\mathrm{NO}_{3}$ & 10 & [47] \\
\hline 3 & $\mathrm{Co}_{1}$ & {$\left[\mathrm{Co}^{\mathrm{II}}\left(\mathrm{L}^{2}\right)\left(\mathrm{H}_{2} \mathrm{O}\right)_{2}\right]\left(\mathrm{ClO}_{4}\right)_{2}$} & $0.55 / 67$ & 335 & n.d. & n.d. & 475 & $\mathrm{Hg}$ arc lamp, $500 \mathrm{~W}$ & 8 & - & $\mathrm{Cl}^{3}$ & 0.2 & [48] \\
\hline 4 & $\mathrm{Co}_{1}$ & {$\left[\mathrm{Co}^{\mathrm{II}}(\mathrm{bpy})_{2}\left(\mathrm{H}_{2} \mathrm{O}\right)\right]\left(\mathrm{ClO}_{4}\right)_{2}$} & $0.34 / 41$ & 206 & n.d. & n.d. & 475 & Hg arc lamp, $500 \mathrm{~W}$ & 8 & n.d. & $\mathrm{Cl}$ & 0.2 & [48] \\
\hline $5 a$ & $\mathrm{Co}_{1}$ & {$\left[\mathrm{Co}^{\mathrm{II}}\left(\mathrm{L}^{3}\right)\left(\mathrm{H}_{2} \mathrm{O}\right)\right]\left(\mathrm{ClO}_{4}\right)_{2}$} & $5.4 / 2700$ & 54 & n.d. & 32 & $>420$ & Xe lamp, $500 \mathrm{~W}$ & 8 & + & $\mathrm{ClO}_{4}$ & 50 & [49] \\
\hline $5 \mathbf{b}$ & $\mathrm{Co}_{1}$ & {$\left[\mathrm{Co}^{\mathrm{II}}\left(\mathrm{L}^{3}\right)\left(\mathrm{H}_{2} \mathrm{O}\right)\right]\left(\mathrm{ClO}_{4}\right)_{2}$} & $0.9 / 450$ & 9 & n.d. & n.d. & $>420$ & Xe lamp, $500 \mathrm{~W}$ & 8 & n.d. & $\mathrm{Cl}$ & 50 & [49] \\
\hline $6 a$ & $\mathrm{Co}_{2}$ & {$\left[\mathrm{Co}^{\mathrm{III}}{ }_{2}(\mu-\mathrm{OH})_{2}(\mathrm{TPA})_{2}\right]\left(\mathrm{ClO}_{4}\right)_{4}$} & $9.3 / 1855$ & 742 & n.d. & 44 & 420 & Xe lamp & 9.3 & - & $\mathrm{ClO}_{4}$ & 2.5 & [50] \\
\hline $6 \mathrm{~b}$ & $\mathrm{CO}_{2}$ & {$\left[\mathrm{Co}^{\mathrm{IIII}}{ }_{2}(\mu-\mathrm{OH})_{2}(\mathrm{TPA})_{2}\right]\left(\mathrm{ClO}_{4}\right)_{4}$} & $5.4 / 1080$ & 2.7 & n.d. & n.d. & 420 & Xe lamp & 9.3 & - & $\mathrm{ClO}_{4}$ & 400 & [50] \\
\hline $7 a$ & $\mathrm{CO}_{2}$ & {$\left[(\mathrm{TPA}) \mathrm{Co}^{\mathrm{IIII}}(\mu-\mathrm{OH})\left(\mu-\mathrm{O}_{2}\right) \mathrm{Co}^{\mathrm{III}}(\mathrm{TPA})\right]\left(\mathrm{ClO}_{4}\right)_{3}$} & $0.1 / 99$ & 58 & 1.4 & n.d. & 470 & LED, $820 \mu \mathrm{E} / \mathrm{s}$ & 8 & $-1+$ & $\mathrm{ClO}_{4}$ & 5 & [51] \\
\hline $7 \mathrm{~b}$ & $\mathrm{Co}_{2}$ & {$\left[(\mathrm{TPA}) \mathrm{Co}^{\mathrm{III}}(\mu-\mathrm{OH})\left(\mu-\mathrm{O}_{2}\right) \mathrm{Co}^{\mathrm{III}}(\mathrm{TPA})\right]\left(\mathrm{ClO}_{4}\right)_{3}+1$ eq. bpy } & $0 / 0$ & 0 & 0 & 0 & 470 & LED, $150 \mathrm{~mW} / \mathrm{cm}^{2}$ & 8 & n.d. & $\mathrm{ClO}_{4}$ & 5 & [52] \\
\hline $8 \mathbf{a}$ & $\mathrm{CO}_{2}$ & {$\left[\left(\mathrm{~L}^{4}\right) \mathrm{Co}^{\mathrm{III}}(\mu-\mathrm{OH})\left(\mu-\mathrm{O}_{2}\right) \mathrm{Co}^{\mathrm{III}}\left(\mathrm{L}^{4}\right)\right]\left(\mathrm{ClO}_{4}\right)_{3}$} & $35 / 2333$ & 233 & n.d. & n.d. & $>420$ & LED, $5.0 \mathrm{~mW} / \mathrm{cm}^{2}$ & 9 & n.d. & $\mathrm{Cl}$ & 10 & [53] \\
\hline $8 b$ & $\mathrm{Co}_{2}$ & {$\left[\left(\mathrm{~L}^{4}\right) \mathrm{Co}^{\mathrm{III}}(\mu-\mathrm{OH})\left(\mu-\mathrm{O}_{2}\right) \mathrm{Co}^{\mathrm{III}}\left(\mathrm{L}^{4}\right)\right]\left(\mathrm{ClO}_{4}\right)_{3}+5$ eq. bpy } & $0 / 0$ & 0 & 0 & 0 & $>420$ & LED, $5.0 \mathrm{~mW} / \mathrm{cm}^{2}$ & 9 & n.d. & $\mathrm{Cl}$ & 10 & [53] \\
\hline 9 & $\mathrm{CO}_{4}$ & {$\left[\mathrm{Co}^{\mathrm{IIII}}{ }_{4} \mathrm{O}_{4}(\mathrm{OAc})_{4}(\mathrm{py})_{4}\right]$} & $16 / 1143$ & $>40$ & 0.02 & n.d. & $>395$ & Arc lamp, 250W, $2 \mathrm{~mW} / \mathrm{cm}^{2}$ & 7 & n.d. & $\mathrm{Cl}$ & 330 & [54] \\
\hline 10 & $\mathrm{Co}_{4}$ & {$\left[\mathrm{Co}^{\mathrm{III}} \mathrm{O}_{4}(\mathrm{OAc})_{4}\left(p-p y-\mathrm{OCH}_{3}\right)_{4}\right]$} & $5.0 / 2520$ & 140 & $\sim 0.04$ & 80 & $>400$ & Halogen lamp & 8 & n.d. & $\mathrm{Cl}$ & 18 & [55] \\
\hline 11a & $\mathrm{Co}_{4}$ & {$\left[\mathrm{Co}^{\mathrm{II}}{ }_{4}\left(\mathrm{~L}^{5}\right)_{4}(\mathrm{OAc})_{4}\left(\mathrm{H}_{2} \mathrm{O}\right)_{2}\right]$} & $15.5 / 1940$ & 20 & 1.8 & n.d. & 470 & LED, $26.1 \mathrm{~mW} / \mathrm{cm}^{2}$ & 7 & - & $\mathrm{Cl}$ & 97 & [56] \\
\hline $11 \mathrm{~b}$ & $\mathrm{Co}_{4}$ & {$\left[\mathrm{Co}_{4}{ }_{4}\left(\mathrm{~L}^{5}\right)_{4}(\mathrm{OAc})_{4}\left(\mathrm{H}_{2} \mathrm{O}\right)_{2}\right]$} & $14.4 / 1800$ & 35 & 4.4 & n.d. & 470 & LED, $26.1 \mathrm{~mW} / \mathrm{cm}^{2}$ & 8 & - & $\mathrm{Cl}$ & 60 & [56] \\
\hline 11c & $\mathrm{Co}_{4}$ & {$\left[\mathrm{Co}^{\mathrm{II}}\left(\mathrm{L}^{5}\right)_{4}(\mathrm{OAc})_{4}\left(\mathrm{H}_{2} \mathrm{O}\right)_{2}\right]$} & $13.4 / 1680$ & 28 & 7 & n.d. & 470 & $\mathrm{LED}, 26.1 \mathrm{~mW} / \mathrm{cm}^{2}$ & 9 & - & $\mathrm{Cl}$ & 60 & [56] \\
\hline 12 & $\mathrm{Co}_{4}$ & {$\left[\mathrm{Co}^{\mathrm{III}} \mathrm{O}_{4}(\mathrm{OAc})_{2}(\mathrm{bpy})_{4}\right]\left(\mathrm{ClO}_{4}\right)_{2}$} & n.d. & n.d. & 0.02 & n.d. & $>380$ & LED & 8 & n.d. & $\mathrm{Cl}$ & 0.2 & [57] \\
\hline $13 a$ & $\mathrm{Co}_{4}$ & {$\left[\mathrm{Co}_{0} \mathrm{III}_{4} \mathrm{O}_{4}(\mathrm{OAc})_{4}(\mathrm{py})_{4}\right]$, crude sample } & $0.3 / 167$ & 0.5 & n.d. & n.d. & $>400$ & $\mathrm{Hg} / \mathrm{Xe}$ arc lamp, $1000 \mathrm{~W}$ & 7 & n.d. & $\mathrm{Cl}$ & 330 & [58] \\
\hline $13 b$ & $\mathrm{Co}_{4}$ & {$\left[\mathrm{Co}_{4} \mathrm{III}_{4} \mathrm{O}_{4}(\mathrm{OAc})_{4}(\mathrm{py})_{4}\right]$ after purification } & $0.06 / 31$ & 0.09 & $\begin{array}{l}2.3 \times \\
10^{-4}\end{array}$ & n.d. & $>400$ & $\mathrm{Hg} / \mathrm{Xe}$ arc lamp, $1000 \mathrm{~W}$ & 7 & n.d. & $\mathrm{Cl}$ & 330 & [58] \\
\hline 14a & $\mathrm{Co}_{4}$ & {$\left[\mathrm{Co}_{4}{ }_{4}\left(\mathrm{~L}^{6}\right)_{4}(\mathrm{OAc})_{2}\left(\mathrm{H}_{2} \mathrm{O}\right)_{2}\right]\left(\mathrm{ClO}_{4}\right)_{2}$} & $9.6 / 1200$ & 96 & 1.2 & n.d. & 470 & LED, $26.1 \mathrm{~mW} / \mathrm{cm}^{2}$ & 8.5 & - & $\mathrm{Cl}$ & 12.5 & [59] \\
\hline $14 \mathrm{~b}$ & $\mathrm{Co}_{4}$ & {$\left[\mathrm{Co}^{\mathrm{II}}{ }_{4}\left(\mathrm{~L}^{6}\right)_{4}(\mathrm{OAc})_{2}\left(\mathrm{H}_{2} \mathrm{O}\right)_{2}\right]\left(\mathrm{ClO}_{4}\right)_{2}$} & $16.0 / 2000$ & 20 & 0.24 & n.d. & 470 & $\mathrm{LED}, 26.1 \mathrm{~mW} / \mathrm{cm}^{2}$ & 8.5 & - & $\mathrm{Cl}$ & 100 & [59] \\
\hline 15 & $\mathrm{Co}_{4-x} \mathrm{Ni}_{x}$ & {$\left[\mathrm{Co}_{1.15} \mathrm{Ni}^{\mathrm{II}}{ }_{2.85}\left(\mathrm{~L}^{6}\right)_{4}(\mathrm{OAc})_{2}\left(\mathrm{H}_{2} \mathrm{O}\right)_{2}\right]\left(\mathrm{ClO}_{4}\right)_{2}$} & $5.5 / 690$ & 6.9 & 0.1 & n.d. & 470 & $\mathrm{LED}, 26.1 \mathrm{~mW} / \mathrm{cm}^{2}$ & 8.5 & n.d. & $\mathrm{Cl}$ & 100 & [59] \\
\hline 16 & $\mathrm{Co}_{3} \mathrm{Ho}$ & {$\left[\mathrm{Co}_{3}^{\mathrm{II}}{ }_{3} \mathrm{Ho}\left(\mathrm{L}^{5}\right)_{4}(\mathrm{OAc})_{5}\left(\mathrm{H}_{2} \mathrm{O}\right)\right]$} & $13.0 / 1630$ & 163 & 5.8 & n.d. & 450 & LED, $26.1 \mathrm{~mW} / \mathrm{cm}^{2}$ & 8 & - & $\mathrm{Cl}$ & 10 & {$[60]$} \\
\hline 17 & $\mathrm{Co}_{3} \mathrm{Er}$ & {$\left[\mathrm{Co}^{\mathrm{II}}{ }_{3} \operatorname{Er}\left(\mathrm{L}^{5}\right)_{4}(\mathrm{OAc})_{5}\left(\mathrm{H}_{2} \mathrm{O}\right)\right]$} & $16.9 / 2110$ & 211 & 5.7 & n.d. & 450 & LED, $26.1 \mathrm{~mW} / \mathrm{cm}^{2}$ & 8 & - & $\mathrm{Cl}$ & 10 & [60] \\
\hline 18 & $\mathrm{Co}_{3} \mathrm{Tm}$ & {$\left[\mathrm{Co}_{3}{ }_{3} \mathrm{Tm}\left(\mathrm{L}^{5}\right)_{4}(\mathrm{OAc})_{5}\left(\mathrm{H}_{2} \mathrm{O}\right)\right]$} & $7.4 / 920$ & 92 & 5.3 & n.d. & 450 & LED, $26.1 \mathrm{~mW} / \mathrm{cm}^{2}$ & 8 & - & $\mathrm{Cl}$ & 10 & [60] \\
\hline 19 & $\mathrm{Co}_{3} \mathrm{Yb}$ & {$\left[\mathrm{Co}_{3}{ }_{3} \mathrm{Yb}\left(\mathrm{L}^{5}\right)_{4}(\mathrm{OAc})_{5}\left(\mathrm{H}_{2} \mathrm{O}\right)\right]$} & $12.8 / 1600$ & 160 & 6.8 & n.d. & 450 & LED, $26.1 \mathrm{~mW} / \mathrm{cm}^{2}$ & 8 & - & $\mathrm{Cl}$ & 10 & [60] \\
\hline 20a & $\mathrm{Co}_{4}$ & $\left\{\mathrm{Co}^{\mathrm{III}} \mathrm{O}_{4}(\mathrm{OAc})_{3}(\mathrm{py})_{4}\right\}\left\{\left(\mathrm{L}^{7}\right) \mathrm{Ru}(\mathrm{bpy})_{2}\right\}$ & $0.15 / 75$ & 5 & $\begin{array}{c}7 \times \\
10^{-3}\end{array}$ & n.d. & $>400$ & Xe lamp, $300 \mathrm{~W}$ & 7 & n.d. & $\mathrm{Cl}$ & 15 & [61] \\
\hline 20b & $\mathrm{Co}_{4}$ & {$\left[\mathrm{Co}^{\mathrm{IIII}}{ }_{4} \mathrm{O}_{4}(\mathrm{OAc})_{4}(\text { py })_{4}\right]+1$ eq. $\left[\mathrm{Ru}(\mathrm{bpy})_{3}\right] \mathrm{Cl}_{2}$} & n.d. & 2 & $\begin{array}{c}5 \times \\
10^{-3}\end{array}$ & n.d. & $>400$ & Xe lamp, $300 \mathrm{~W}$ & 7 & n.d. & $\mathrm{Cl}$ & 15 & [61] \\
\hline 21 & $\mathrm{Co}_{4}$ & $\left\{\mathrm{Co}^{\mathrm{IIII}}{ }_{4} \mathrm{O}_{4}(\mathrm{OAc})_{2}(\mathrm{py})_{4}\right\}_{2}\left\{\left(\mathrm{~L}^{8}\right) \mathrm{Ru}(\mathrm{bpy})_{2}\right\}_{2}$ & $0.74 / 360$ & 24 & 0.02 & n.d. & $>400$ & Xe lamp, $300 \mathrm{~W}$ & 7 & n.d. & $\mathrm{Cl}$ & 15 & [61] \\
\hline 22a & $\mathrm{Co}_{4}$ & $\mathrm{Na}_{10}\left[\mathrm{Co}_{4}\left(\mathrm{H}_{2} \mathrm{O}\right)_{2}\left(\mathrm{VW}_{9} \mathrm{O}_{34}\right)_{2}\right]$ & n.d./0.15 & 300 & $>1600$ & - & - & $\begin{array}{l}\text { Chemical oxidation with } \\
\left.[\text { Ru(bipv) }]_{2}\right]^{3+}\end{array}$ & 9 & - & $\mathrm{ClO}_{4}$ & 0.5 & [62] \\
\hline 22b & $\mathrm{Co}_{4}$ & $\mathrm{Na}_{10}\left[\mathrm{Co}_{4}\left(\mathrm{H}_{2} \mathrm{O}\right)_{2}\left(\mathrm{VW}_{9} \mathrm{O}_{34}\right)_{2}\right]$ & $3.0 / 1484$ & 742 & 4 & 61 & 455 & LED, $135 \mathrm{~mW} / \mathrm{cm}^{2}$ & 9 & - & $\mathrm{Cl}$ & 2.0 & [62] \\
\hline $22 \mathrm{c}$ & $\mathrm{Co}_{4}$ & $\mathrm{Na}_{10}\left[\mathrm{Co}_{4}\left(\mathrm{H}_{2} \mathrm{O}\right)_{2}\left(\mathrm{VW}_{9} \mathrm{O}_{34}\right)_{2}\right]$ & $1.7 / 842$ & 4210 & n.d. & 48 & 455 & LED, $135 \mathrm{~mW} / \mathrm{cm}^{2}$ & 9 & - & $\mathrm{Cl}$ & 0.2 & [62] \\
\hline 23 & $\mathrm{Co}_{4}$ & {$\left[\mathrm{Co}_{4}\left(\mathrm{H}_{2} \mathrm{O}\right)_{4}\left(\mathrm{HL}^{9}\right)_{2}\left(\mathrm{~L}^{9}\right)_{2}\right]$} & $13.2 / 1324$ & 662 & 0.03 & n.d. & $>420$ & Xe lamp, $300 \mathrm{~W}, 26.4 \mathrm{~mW} / \mathrm{cm}^{2}$ & 9 & - & $\mathrm{ClO}_{4}$ & 2 & {$[63]$} \\
\hline
\end{tabular}


Table 1. Cont.

\begin{tabular}{|c|c|c|c|c|c|c|c|c|c|c|c|c|c|}
\hline $\mathbf{N}$ & Core & (Pre)catalyst & $\begin{array}{c}\mathrm{O}_{2} \\
\text { Evolution, } \\
\mu \mathrm{mol} / \mu \mathrm{M}\end{array}$ & TON $^{1}$ & $\mathrm{TOF}^{2}$ & $\underset{\%}{\mathrm{QE}^{3}}$ & $\lambda^{4}, \mathrm{~nm}$ & Irradiation Source & $\mathrm{pH}$ & $\mathrm{NP}^{5}$ & Anion ${ }^{6}$ & $\begin{array}{c}{[\mathrm{cat}]_{0},} \\
\mu \mathrm{M}\end{array}$ & Ref. \\
\hline $24 a$ & $\mathrm{Co}_{6}$ & $\mathrm{~K}_{12}\left[\mathrm{Co}\left(\mathrm{L}^{9}\right)\right]_{6}$ & $1.1 / 113$ & 1125 & 35.3 & 5.9 & 460 & LED, $33.8 \mathrm{~mW} / \mathrm{cm}^{2}$ & 9 & n.d. & $\mathrm{Cl}$ & 0.1 & [64] \\
\hline $24 \mathrm{~b}$ & $\mathrm{Co}_{6}$ & $\mathrm{~K}_{12}\left[\mathrm{Co}\left(\mathrm{L}^{9}\right)\right]_{6}$ & $4.4 / 435$ & 4350 & 162.6 & 27.1 & 460 & LED, $33.8 \mathrm{~mW} / \mathrm{cm}^{2}$ & 9 & n.d. & $\mathrm{ClO}_{4}$ & 0.1 & [64] \\
\hline $24 \mathrm{c}$ & $\mathrm{Co}_{6}$ & $\mathrm{~K}_{12}\left[\mathrm{Co}\left(\mathrm{L}^{9}\right)\right]_{6}$ & $11.7 / 1169$ & 167 & 4.4 & 51.5 & 460 & LED, $33.8 \mathrm{~mW} / \mathrm{cm}^{2}$ & 9 & n.d. & $\mathrm{Cl}$ & 7 & [64] \\
\hline 25 & $\mathrm{Co}_{7}$ & $\mathrm{Na}_{12}\left[\left\{\mathrm{Co}^{\mathrm{II}}{ }_{7} \mathrm{As}_{6} \mathrm{O}_{9}(\mathrm{OH})_{6}\right\}\left(\mathrm{SiW}_{9} \mathrm{O}_{34}\right)_{2}\right]$ & $2.3 / 115$ & 115.2 & 0.14 & n.d. & $>420$ & Xe lamp, 300W & 8 & - & $\mathrm{Cl}$ & 1 & {$[65]$} \\
\hline 26a & $\mathrm{Co}_{7}$ & {$\left[\mathrm{Co}_{5} \mathrm{II}^{\mathrm{IIII}}{ }_{2}(\mathrm{mdea})_{4}\left(\mathrm{~N}_{3}\right)_{2}\left(\mathrm{CH}_{3} \mathrm{CN}\right)_{6}(\mathrm{OH})_{2}\left(\mathrm{H}_{2} \mathrm{O}\right)_{2}\right]\left(\mathrm{ClO}_{4}\right)_{4}$} & $10.7 / 1070$ & 43 & n.d. & n.d. & 450 & LED & 9 & n.d. & $\mathrm{Cl}$ & 25 & [66] \\
\hline 26b & $\mathrm{Co}_{7}$ & {$\left[\mathrm{Co}_{5} \mathrm{II}_{5} \mathrm{Co}^{\mathrm{III}}{ }_{2}(\mathrm{mdea})_{4}\left(\mathrm{~N}_{3}\right)_{2}\left(\mathrm{CH}_{3} \mathrm{CN}\right)_{6}(\mathrm{OH})_{2}\left(\mathrm{H}_{2} \mathrm{O}\right)_{2}\right]\left(\mathrm{ClO}_{4}\right)_{4}$} & $22 / 2200$ & 88 & n.d. & n.d. & 450 & LED & 9 & n.d. & $\mathrm{ClO}_{4}$ & 25 & [66] \\
\hline $26 c$ & $\mathrm{Co}_{7}$ & {$\left[\mathrm{Co}^{\mathrm{II}} \mathrm{Co}^{\mathrm{IIII}}{ }_{2}(\mathrm{mdea})_{4}\left(\mathrm{~N}_{3}\right)_{2}\left(\mathrm{CH}_{3} \mathrm{CN}\right)_{6}(\mathrm{OH})_{2}\left(\mathrm{H}_{2} \mathrm{O}\right)_{2}\right]\left(\mathrm{ClO}_{4}\right)_{4}$} & $10.5 / 1050$ & 210 & n.d. & n.d. & 450 & LED & 9 & n.d. & $\mathrm{Cl}$ & 5 & [66] \\
\hline 27a & $\mathrm{Co}_{8}$ & $\mathrm{~K}_{8} \mathrm{Na}_{8}\left[\left(\mathrm{SiW}_{9} \mathrm{O}_{34}\right)_{2} \mathrm{Co}_{8}(\mathrm{OH})_{6}\left(\mathrm{H}_{2} \mathrm{O}_{2}\left(\mathrm{CO}_{3}\right)_{3}\right]\right.$ & $16.4 / 1090$ & 545 & 3.1 & 35.8 & $>420$ & LED, $5.1 \mathrm{~mW} / \mathrm{cm}^{2}$ & 9 & - & $\mathrm{Cl}$ & 2 & [67] \\
\hline $27 \mathrm{~b}$ & $\mathrm{Co}_{8}$ & $\mathrm{~K}_{8} \mathrm{Na}_{8}\left[\left(\mathrm{SiW}_{9} \mathrm{O}_{34}\right)_{2} \mathrm{Co}_{8}(\mathrm{OH})_{6}\left(\mathrm{H}_{2} \mathrm{O}\right)_{2}\left(\mathrm{CO}_{3}\right)_{3}\right]$ & $10.8 / 718$ & 1436 & 10 & 28.8 & $>420$ & LED, $5.1 \mathrm{~mW} / \mathrm{cm}^{2}$ & 9 & n.d. & $\mathrm{Cl}$ & 0.5 & [67] \\
\hline 28 & $\mathrm{Co}_{9}$ & $\mathrm{~K}_{16}\left[\mathrm{Co}_{9}\left(\mathrm{H}_{2} \mathrm{O}\right)_{6}(\mathrm{OH})_{3}\left(\mathrm{PW}_{9} \mathrm{O}_{34}\right)_{3}\right]$ & $1.0 / 67$ & 10 & $\begin{array}{c}5 \times \\
10^{-3}\end{array}$ & n.d. & $>375$ & $\begin{array}{l}\text { Tungsten lamp, } 150 \mathrm{~W}, 90 \\
\mathrm{~mW} / \mathrm{cm}^{2}\end{array}$ & 8 & n.d. & n.d. & 6.6 & [68] \\
\hline 29a & $\mathrm{Co}_{15}$ & $\mathrm{Na}_{5}\left[\mathrm{Co}_{6}\left(\mathrm{H}_{2} \mathrm{O}\right)_{30}\left\{\mathrm{Co}_{9} \mathrm{Cl}_{2}(\mathrm{OH})_{3}\left(\mathrm{H}_{2} \mathrm{O}\right)_{9}\left(\mathrm{SiW}_{8} \mathrm{O}_{31}\right)_{3}\right\}\right]$ & $3.1 / 207$ & 53 & $\begin{array}{l}21 \times \\
10^{-3}\end{array}$ & n.d. & $>375$ & $\begin{array}{l}\text { Tungsten lamp, } 150 \mathrm{~W}, 90 \\
\mathrm{~mW} / \mathrm{cm}^{2}\end{array}$ & 8 & n.d. & n.d. & 3.4 & [68] \\
\hline $29 \mathrm{~b}$ & $\mathrm{Co}_{15}$ & $\mathrm{Na}_{5}\left[\mathrm{Co}_{6}\left(\mathrm{H}_{2} \mathrm{O}\right)_{30}\left\{\mathrm{Co}_{9} \mathrm{Cl}_{2}(\mathrm{OH})_{3}\left(\mathrm{H}_{2} \mathrm{O}\right)_{9}\left(\mathrm{SiW}_{8} \mathrm{O}_{31}\right)_{3}\right\}\right]$ & $4.1 / 273$ & 28 & $\begin{array}{l}19 \times \\
10^{-3}\end{array}$ & 5.5 & 450 & LED, $7 \mathrm{~mW}$ & 8 & n.d & n.d. & 9.8 & [68] \\
\hline 30 & $\mathrm{Co}_{16}$ & $\mathrm{Na}_{22} \mathrm{Rb}_{6}\left[\left\{\mathrm{Co}_{4}(\mathrm{OH})_{3} \mathrm{PO}_{4}\right\}_{4}\left(\mathrm{PW}_{9} \mathrm{O}_{34}\right)_{4}\right]$ & $2.0 / 133$ & 37 & $\begin{array}{l}24 \times \\
10^{-3}\end{array}$ & n.d. & $>375$ & $\begin{array}{l}\text { Tungsten lamp, } 150 \mathrm{~W}, 90 \\
\mathrm{~mW} / \mathrm{cm}^{2}\end{array}$ & 8 & n.d. & n.d. & 3.6 & [68] \\
\hline 31a & $\mathrm{Co}_{1}$ & $\mathrm{Co}\left(\mathrm{NO}_{3}\right)_{2}$ & $12.2 / 1219$ & 762 & n.d. & n.d. & $>420$ & $\mathrm{LED}, 5.1 \mathrm{~mW} / \mathrm{cm}^{2}$ & 9 & + & $\mathrm{ClO}_{4}$ & 1.6 & [46] \\
\hline $31 \mathrm{~b}$ & $\mathrm{Co}_{1}$ & $\mathrm{Co}\left(\mathrm{NO}_{3}\right)_{2}$ & $5.2 / 2600$ & 52 & n.d. & n.d. & $>420$ & Xe lamp, $500 \mathrm{~W}$ & 8 & + & $\mathrm{ClO}_{4}$ & 50 & [49] \\
\hline $31 \mathrm{c}$ & $\mathrm{Co}_{1}$ & $\mathrm{Co}\left(\mathrm{NO}_{3}\right)_{2}$ & $4.6 / 310$ & 4.3 & $\begin{array}{c}1.92 \times \\
10^{-3}\end{array}$ & 11 & 450 & LED, $42 \mathrm{~mW}$ & 8 & - & $\mathrm{Cl}$ & 72 & [69] \\
\hline 31d & $\mathrm{Co}_{1}$ & $\mathrm{Co}\left(\mathrm{NO}_{3}\right)_{2}$ & $11.1 / 1112$ & 139 & n.d. & n.d. & $>420$ & Xe lamp, $300 \mathrm{~W}, 26.4 \mathrm{~mW} / \mathrm{cm}^{2}$ & 8 & + & $\mathrm{ClO}_{4}$ & 8 & [63] \\
\hline $31 \mathrm{e}$ & $\mathrm{Co}_{1}$ & $\mathrm{Co}\left(\mathrm{NO}_{3}\right)_{2}$ & $19.5 / 1952$ & 244 & n.d. & n.d. & $>420$ & Xe lamp, $300 \mathrm{~W}, 26.4 \mathrm{~mW} / \mathrm{cm}^{2}$ & 9 & + & $\mathrm{ClO}_{4}$ & 8 & [63] \\
\hline $31 \mathrm{f}$ & $\mathrm{Co}_{1}$ & $\mathrm{Co}\left(\mathrm{NO}_{3}\right)_{2}$ & $3 / 300$ & 150 & n.d. & n.d. & $>420$ & Xe lamp, $300 \mathrm{~W}, 26.4 \mathrm{~mW} / \mathrm{cm}^{2}$ & 8 & + & $\mathrm{ClO}_{4}$ & 2 & [63] \\
\hline $32 a$ & $\mathrm{Co}_{1}$ & $\mathrm{Co}\left(\mathrm{ClO}_{4}\right)_{2}$ & $0.4 / 400$ & 570 & 19 & n.d. & 470 & $\mathrm{LED}, 150 \mathrm{~mW} / \mathrm{cm}^{2}$ & 8 & + & $\mathrm{ClO}_{4}$ & 0.7 & [52] \\
\hline $32 b$ & $\mathrm{Co}_{1}$ & $\mathrm{Co}\left(\mathrm{ClO}_{4}\right)_{2}$ & $0.25 / 250$ & 500 & 16 & n.d. & 470 & LED, $150 \mathrm{~mW} / \mathrm{cm}^{2}$ & 8 & + & $\mathrm{ClO}_{4}$ & 0.5 & [52] \\
\hline $32 \mathrm{c}$ & $\mathrm{Co}_{1}$ & $\mathrm{Co}\left(\mathrm{ClO}_{4}\right)_{2}+8$ eq. bpy & $0 / 0$ & 0 & 0 & n.d. & 470 & LED, $150 \mathrm{~mW} / \mathrm{cm}^{2}$ & 8 & + & $\mathrm{ClO}_{4}$ & 0.5 & [52] \\
\hline $33 a$ & $\mathrm{Co}_{1}$ & $\mathrm{Co}(\mathrm{OAc})_{2}$ & $5.4 / 680$ & 7 & n.d. & n.d. & 470 & LED, $26.1 \mathrm{~mW} / \mathrm{cm}^{2}$ & 7 & + & $\mathrm{Cl}$ & 250 & [56] \\
\hline $33 b$ & $\mathrm{Co}_{1}$ & $\mathrm{Co}(\mathrm{OAc})_{2}$ & $9.2 / 924$ & 132 & 3.1 & 36.1 & 460 & LED, $33.8 \mathrm{~mW} / \mathrm{cm}^{2}$ & 9 & n.d. & $\mathrm{ClO}_{4}$ & 7 & [64] \\
\hline
\end{tabular}

${ }^{1}$ Moles of product per mol of catalyst; ${ }^{2}$ Moles of product produced per mol of catalyst per a certain period of time; ${ }^{3}$ Quantum efficiency, moles of $\mathrm{O}_{2}$ produced per moles of absorbed photons; ${ }^{4}$ Irradiation wavelength, as reported; ${ }^{5}$ Formation of nanoparticles; ${ }^{6}$ anion of the $\left[\mathrm{Ru}(\mathrm{bpy})_{3}\right]^{2+}$ photosensitizer; ${ }^{7}$ no data. 


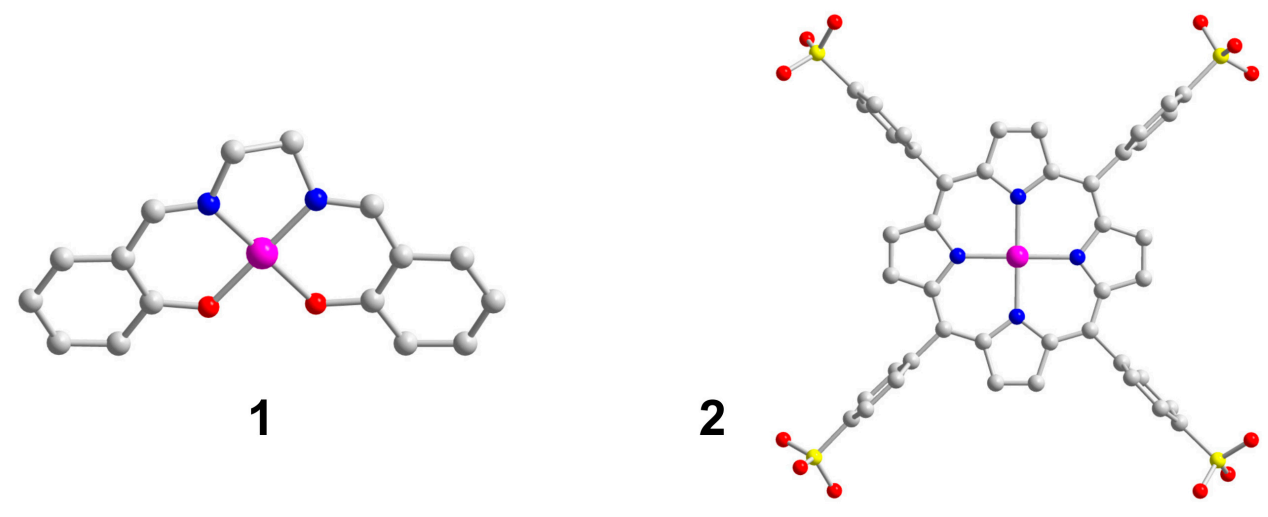

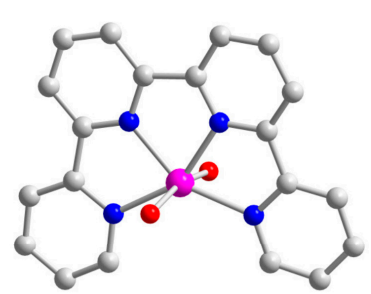

3

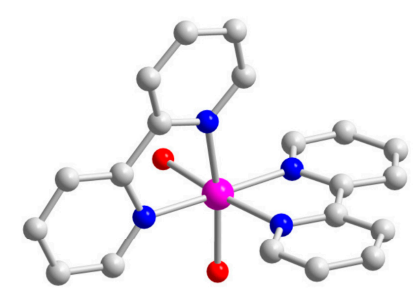

4

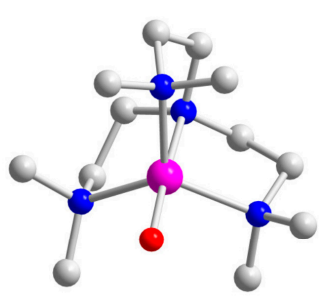

5

Figure 2. Structures of complexes 1-5. Color scheme: Co, pink; O, red; N, blue; S, yellow; C, grey.

Complexes of porphyrin ligands are known to catalyze a wide range of reactions due to the pronounced stability of porphyrins, their redox activity, and ability to stabilize high-valent metal-oxo species of iron, manganese, ruthenium, and other metals [70-72]. A series of the water-soluble porphyrin complexes of cobalt have been tested as WOCs. The best results were obtained using the catalyst [Co(TPPS)] (2) with porphyrin ligand TPPS (meso-tetrakis(4-sulfophenyl)porphyrin) (Figure 2), reaching the TOF value of $0.17 \mathrm{~s}^{-1}$ at $\mathrm{pH} 11$ [47]. At lower or higher $\mathrm{pH}$, TOF did not exceed $0.05 \mathrm{~s}^{-1}$. From the second order dependence of the initial rate of $\mathrm{O}_{2}$ formation on the [2] $]_{0}$, as well as from the DFT calculations, it was proposed that two molecules of $\mathbf{2}$ are required for completion of the water oxidation catalytic cycle. The proposed catalytic cycle presumes coupling of the $\mathrm{Co}-\mathrm{O} \bullet$ radicals as the principal mechanistic step, corresponding to the so-called I2M type of mechanisms (Scheme 2) [7]. One may notice, however, that for the electrocatalytic water oxidation catalyzed by cobalt porphyrins, the water nucleophilic attack (WNA) mechanism was proposed [73]. No nanoparticles formation was observed by DLS measurements. Appearance of the Soret band of porphyrin after mixing of $\left[\mathrm{Ru}(\mathrm{bpy})_{3}\right]^{3+}$ with $\mathbf{2}$ also suggests that $\mathbf{2}$ is responsible for the catalytic activity. An unusual feature of this catalytic system is the use of nitrate salt of the $\left[\mathrm{Ru}(\mathrm{bpy})_{3}\right]^{2+}$ photosensitizer (Table 1 ) instead of common chloride or perchlorate ones.

Two complexes, 3 and $\mathbf{4}$, with polypyridine ligands (Figure 2) were tested as WOCs and revealed similar activities (Table 1) [48]. Chemical oxidation with $[\mathrm{Ru}(\mathrm{bpy})]^{3+}$ was performed resulting on TON values of 160 and 70 for 3 and 4, respectively. No formation of cobalt oxide nanoparticles or leaching of the cobalt ions was observed under catalytic conditions (both in light-driven and chemical oxidations), as evidenced by ESI-MS and DLS tests. The authors proposed the existence of two active intermediates, which ratio is defined by relative stability of the molecular intermediate [48]. One may notice that very low concentrations of the catalysts in the case of 3 and $4(0.2 \mu \mathrm{M})$ may prevent correct determination of the nanoparticles or other decomposition products by conventional methods. 


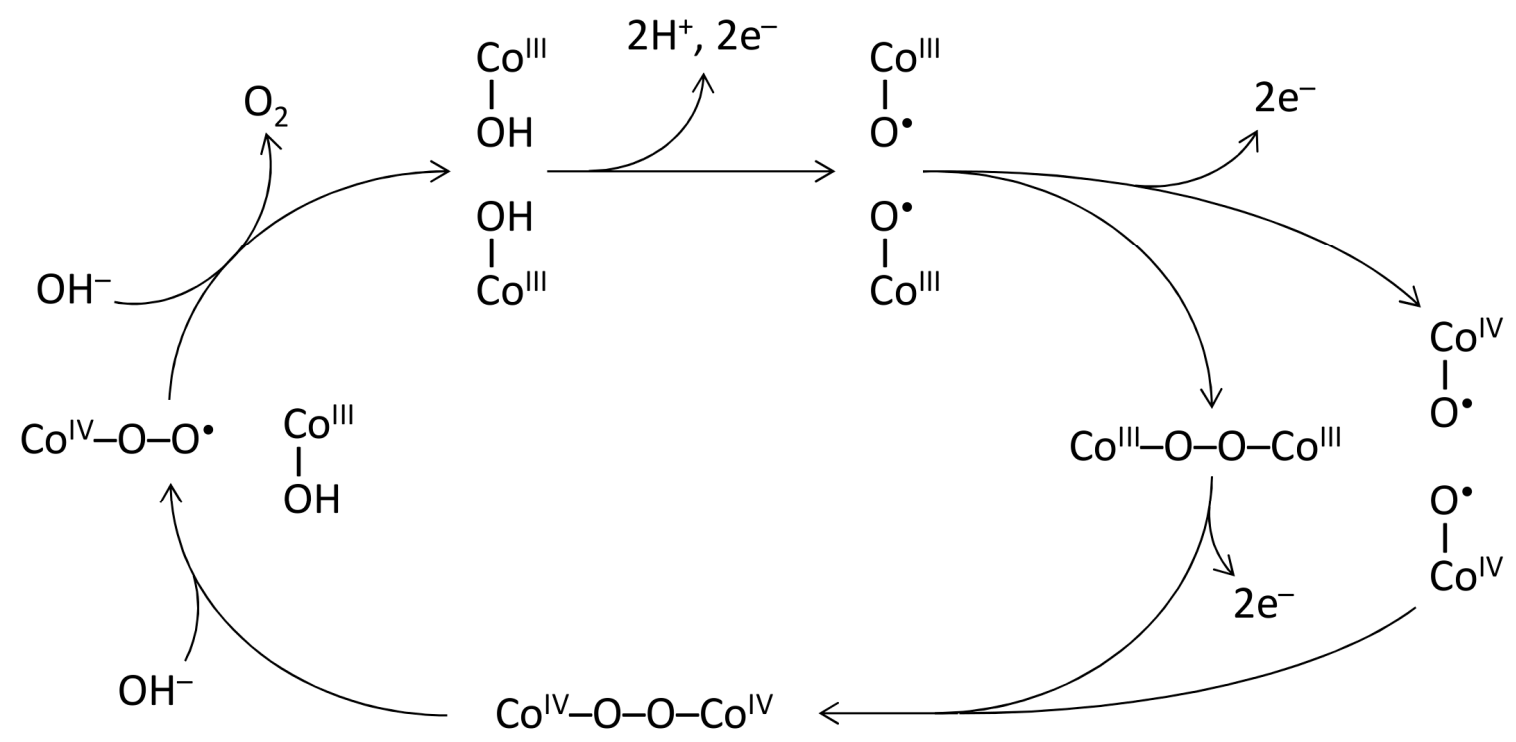

Scheme 2. Proposed pathways for the $\mathrm{O}_{2}$ formation in the water oxidation catalyzed by 2 .

A series of mononuclear cobalt complexes with polydentate $\mathrm{N}$-donor ligands was prepared and studied as catalysts in the light-driven water oxidation. The most active complex $\left[\mathrm{Co}\left(\mathrm{L}^{3}\right)\right](5)$ having tris( $\mathrm{N}_{1} \mathrm{~N}^{\prime}$-(dimethylamino)ethyl)amine ligand (Figure 2) showed the TON values up to 54 and quantum yield of $\mathrm{O}_{2}$ up to $32 \%$ (5a, Table 1) [49]. Very similar results were obtained for $\mathrm{Co}\left(\mathrm{NO}_{3}\right)_{2}$ as pre-catalyst (31b, Table 1), suggesting decomposition of complex $\mathbf{5}$ under catalytic conditions. Formation of nanoparticles with sizes ranging from 10 to $50 \mathrm{~nm}$ was confirmed by DLS and TEM (transmission electron microscopy) for the case of 5 . The size of particles and their aggregation behavior were different for 5 and $\mathrm{Co}\left(\mathrm{NO}_{3}\right)_{2}$. Moreover, the dependence of the yield of $\mathrm{O}_{2}$ on the pre-catalyst concentration showed no changes at $\left[\mathrm{Co}\left(\mathrm{NO}_{3}\right)_{2}\right]_{0}>1 \mathrm{mM}$, while for $[5]_{0}>0.1 \mathrm{mM}$ the catalytic activity showed rapid decay until no evolution of $\mathrm{O}_{2}$ at $[5]_{0}=2.5 \mathrm{mM}$. Formation of $\mathrm{CO}_{2}$ in the catalytic system $\left[\mathrm{Ru}(\mathrm{bpy})_{3}\right]^{2+} / 5 / \mathrm{S}_{2} \mathrm{O}_{8}{ }^{2-}$, with elevated concertation of persulfate $(50 \mathrm{mM})$, unambiguously pointed out the oxidation of organic ligand of 5 . The authors concluded that although complex 5 (and other complexes of the series) acts as a pre-catalyst, the nature of the ligand influences the structure and composition of the oxide nanoparticles formed and therefore the catalytic activity as well [49]. As a final remark, one may notice a strong influence of the nature of anion of $\left[\mathrm{Ru}(\mathrm{bpy})_{3}\right]^{2+}$ photosensitizer, where perchlorate system $(\mathbf{5 a})$ is six times more active than the chloride one $(\mathbf{5 b})$.

The cobalt complex $\left[\mathrm{Co}_{2}(\mu-\mathrm{OH})_{2}(\mathrm{TPA})_{2}\right]\left(\mathrm{ClO}_{4}\right)_{4}(6)$ with tris(2-pyridylmethyl)amine (TPA) was synthesized by dimerization of the mononuclear complexes $\left[\mathrm{Co}{ }^{\mathrm{III}}(\mathrm{TPA}) \mathrm{Cl}_{2}\right]\left(\mathrm{ClO}_{4}\right)$ in the presence of $\mathrm{AgClO}_{4}$ as a halogen acceptor [50]. The crystal structure of 6 , features a binuclear core where metal atoms are mediated by the bridging oxido ligands (Figure 3). The highest TON of 742 was obtained for low concentration of the catalyst (6a, Table 1). Increase of $[6]_{0}$ led to lower evolution of $\mathrm{O}_{2}(\mathbf{6 b})$. Chemical water oxidation with $[\mathrm{Ru}(\mathrm{bpy})]^{3+}$ showed the TON of 4.3. According to DFT calculations, the active species are formed from the two-electron oxidation of 6 (Scheme 3). As evidenced by the ${ }^{1} \mathrm{H}$ NMR and DLS experiments performed for $[6]_{0}=0.4 \mathrm{mM}$, complex $\mathbf{6}$ is stable during the photocatalytic reaction. Also, no $\mathrm{CO}_{2}$ evolution, attributable to TPA ligand oxidation, was detected. These results are in accord with the ones observed for the TPA family of ligands in various oxidative processes. For instance, iron complexes with TPA are known to stabilize $\mathrm{Fe}^{\mathrm{IV}}$ and $\mathrm{Fe}^{\mathrm{V}}$ species capable of abstracting $\mathrm{H}$ atoms from $\mathrm{sp}^{3} \mathrm{C}-\mathrm{H}$ bonds $[74,75]$. 


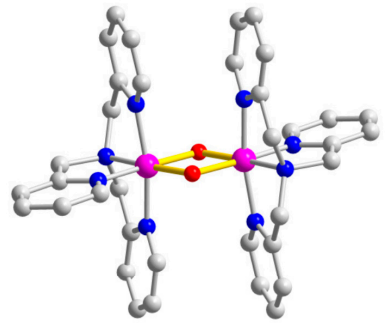

6

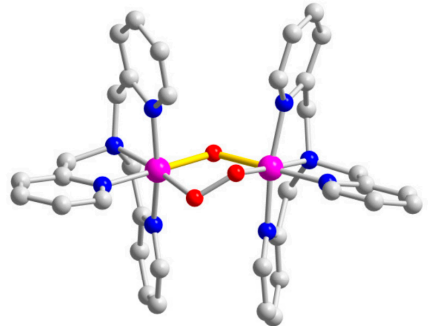

7

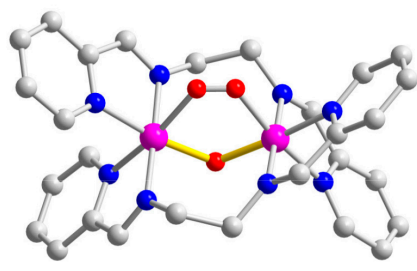

8

Figure 3. Structures of complexes 6-8. Color scheme: Co, pink; O, red; N, blue; S, yellow; C, grey. $\mathrm{Co}-\mathrm{O}-\mathrm{Co}$ bonds are highlighted by yellow.

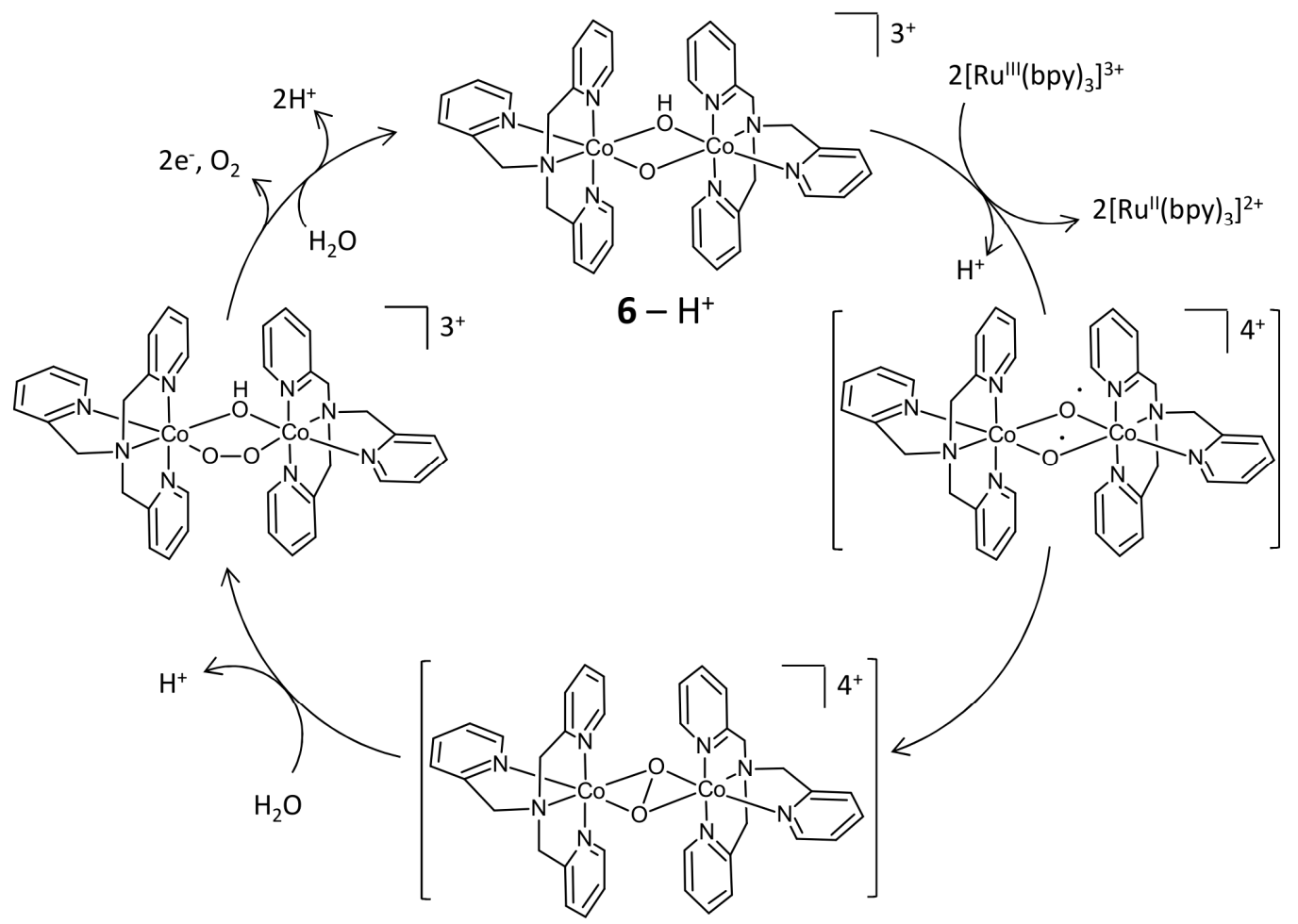

Scheme 3. Proposed pathways for the $\mathrm{O}_{2}$ formation in the water oxidation catalyzed by 6 .

In contrast to 6 , obtained from the $\mathrm{Co}^{\mathrm{III}}$ starting material, dimerization of $\left[\mathrm{Co}^{\mathrm{II}}(\mathrm{TPA}) \mathrm{Cl}\right] \mathrm{Cl}$ complexes in the presence of $\mathrm{LiClO}_{4}$ in open air, led to in situ oxidation of cobalt to $\mathrm{Co}^{3+}$ and formation of the Co-O-O-Co bridge in the complex [(TPA) $\left.\mathrm{Co}(\mu-\mathrm{OH})\left(\mu-\mathrm{O}_{2}\right) \mathrm{Co}(\mathrm{TPA})\right]\left(\mathrm{ClO}_{4}\right)_{3}(7)$ (Figure 3) [51]. The compound was found to be stable at ambient conditions and showed moderate activity as a WOC at $\mathrm{pH} 8$ with TON $=58$. The authors performed DLS measurements and concluded that no $\mathrm{CoO}_{\mathrm{x}}$ nanoparticles are formed during the photocatalytic reaction, while the control DLS experiment using $\mathrm{Co}\left(\mathrm{ClO}_{4}\right)_{2}$ as a catalyst revealed nanoparticles with ca. $100 \mathrm{~nm}$ size after irradiation. However, just two years later these results were reinvestigated by a different group of authors [52]. The use of an extended set of methods disclosed that the catalytic system based on complex 7 is in fact heterogeneous and contains $\mathrm{CoO}_{x}$ nanoparticles. Specifically, the water oxidation activity using the pre-catalyst 7 was completely suppressed when adding chelating ligands such as EDTA (ethylenediaminetetraacetic acid) or bpy (Figure $4 \mathrm{a}$ ). The presence of just $0.1 \mathrm{mM}$ of EDTA led to zero yields of $\mathrm{O}_{2}$ for $0.5 \mathrm{mM}$ of 7 . The test with bipyridine requires its larger amounts, but one equivalent of bpy ( $5 \mu \mathrm{M}$ of bpy per $5 \mu \mathrm{M}$ of 7 ) is enough for quenching the catalytic activity of 7 [52]. Such behavior is consistent with that observed for $\mathrm{Co}\left(\mathrm{ClO}_{4}\right)_{2}$ salt as a catalyst, which activity at $0.7 \mu \mathrm{M}$ concentration (32a, Table 1 ; Figure $\left.4 \mathrm{~b}\right)$ is 
completely quenched with eight equivalents of bpy (32b, Table 1). A question appears, namely, why earlier DSL measurements did not detect nanoparticles presumably formed upon degradation of complex 7? A general explanation could be the different experimental conditions in these cases. It was mentioned that the DLS method might not detect small particles (at low amounts) formed in the course of reaction. Also, as can be seen from the systems 31 and 32 (Table 1), cobalt cations act as very efficient pre-catalysts at micromolar concentrations. Thus, even a small leaching of cobalt cations (captured by EDTA and bpy) from the initial coordination compound may be responsible for the pronounced catalytic activity, initially associated to the complex. In any case, these studies clearly demonstrate that the conclusion about the catalyst stability should not be made based on a single experimental method, such as DLS.

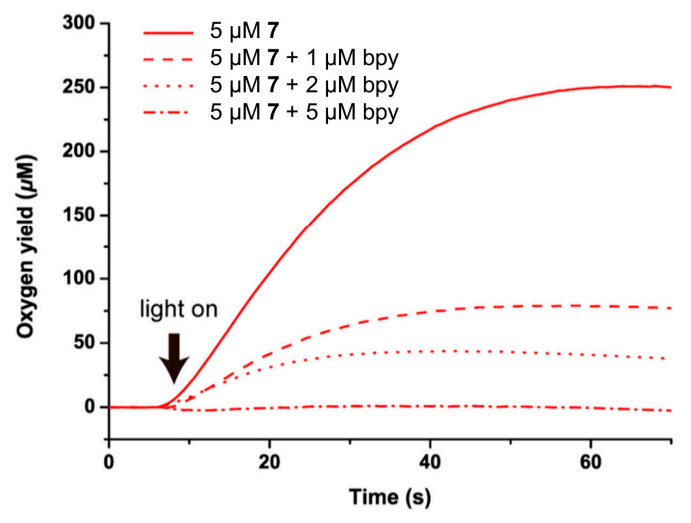

(a)

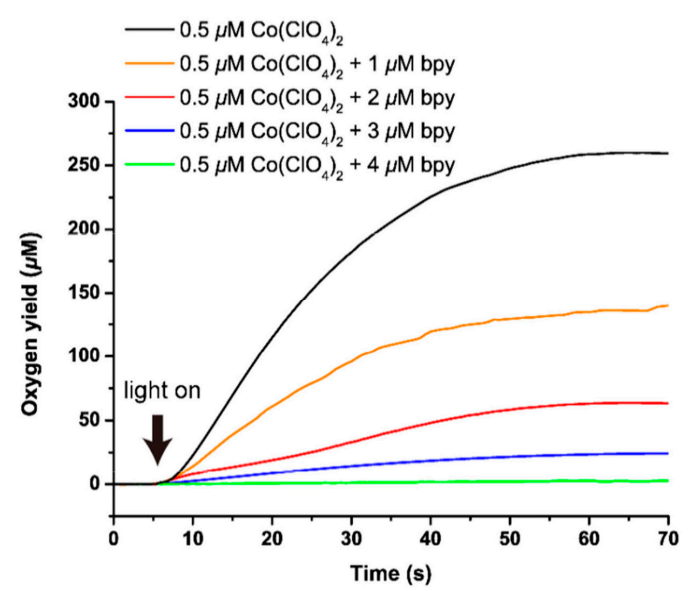

(b)

Figure 4. Accumulations of the oxygen in the course of water oxidation catalyzed by complex 7 (a) or $\mathrm{Co}\left(\mathrm{ClO}_{4}\right)_{2}(\mathbf{b})$, in the presence of various amounts of bipyridine (bpy) chelating agent. Adapted with permission from [52], American Chemical Society, 2016.

By reacting of the Schiff base ligand, N,N-bis(pyridin-2-ylmethylene)ethane-1,2-diimine $\left(\mathrm{L}^{4}\right)$, and $\mathrm{Co}\left(\mathrm{ClO}_{4}\right)_{2}$ in excess of pyridine the binuclear complex $\left[\left(\mathrm{L}^{4}\right) \mathrm{Co}^{\mathrm{III}}(\mu-\mathrm{OH})\left(\mu-\mathrm{O}_{2}\right) \mathrm{Co}^{\mathrm{III}}\left(\mathrm{L}^{4}\right)\right]\left(\mathrm{ClO}_{4}\right)_{3}(8)$ has been prepared [53]. The structure of its core is similar to that observed for 7 (Figure 3). The light-driven water oxidation activity was studied by the independent group of authors, revealing TON values and oxygen concentrations much higher than those for 7 (Table 1). However, the tests performed in the presence of bpy ligand showed complete suppression of the catalytic activity with five equivalents of bpy ( $7 \mathbf{b}$, Table 1$)$, indicating that the observed activity could be associated to the free cobalt cations, rather than complex 7 .

\section{Tetranuclear Cubanes $\mathrm{Co}_{4} \mathrm{O}_{4}$ or $\mathrm{Co}_{4-x} \mathrm{M}_{\mathrm{x}} \mathrm{O}_{4}$}

In $2011 \mathrm{McC}$ col at al. reported the water oxidation catalytic activity of the tetranuclear complex $\left[\mathrm{Co}_{4}^{\mathrm{III}}{ }_{4} \mathrm{O}_{4}(\mathrm{Ac})_{4}(\mathrm{py})_{4}\right](9)$ [54]. This coordination compound was known earlier, and was also studied as a catalyst for the alcohols oxidation [76]. Its structure (Figure 5) represents a cubane core $\mathrm{Co}_{4}\left(\mu_{3}-\mathrm{O}\right)_{4}$, resembling that found in the PSII protein $\left(\mathrm{CaMn}_{3} \mathrm{O}_{4}\right)$. The TOF of $0.02 \mathrm{~s}^{-1}$ exhibited by 9 for the light-driven oxidation was among, as of 2011, the highest known, resulting in high interest in the tetranuclear cobalt complexes as WOCs. The stability of the catalyst under the conditions of experiment was confirmed by the ${ }^{1} \mathrm{H}$ NMR (constant signals from acetate and pyridine ligands). Furthermore, the authors studied dependence of the lag time on the catalyst concentration. Lag period is expected when a catalyst undergoes transformations to active species (such as $\mathrm{CoO}_{\mathrm{x}}$ nanoparticles) after irradiation begins, thus a lag time smaller than that for cobalt salt suggests the stability of the catalyst. The catalytic system based on complex 9 showed small lag time (less than $20 \mathrm{~s}$ for $[9]_{0} \sim 4 \mathrm{mM}$ ), and this 
was associated by the authors to low oxidant/catalyst ratio, while the cobalt salt showed a lag time of almost $200 \mathrm{~s}$ under the same conditions [54].
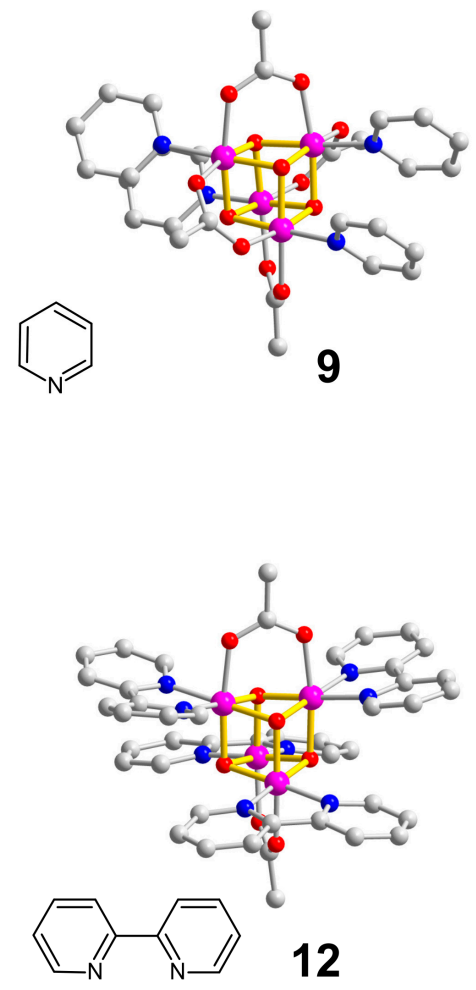
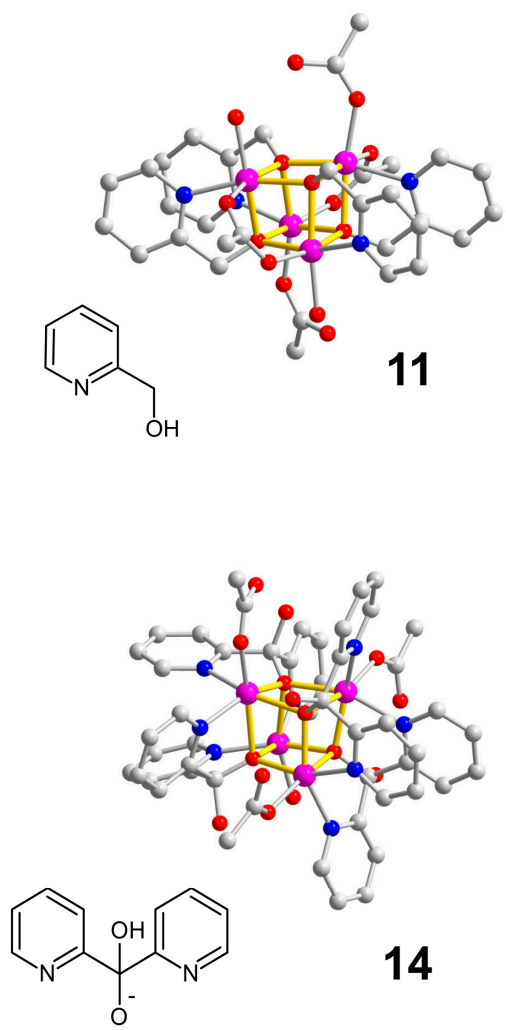

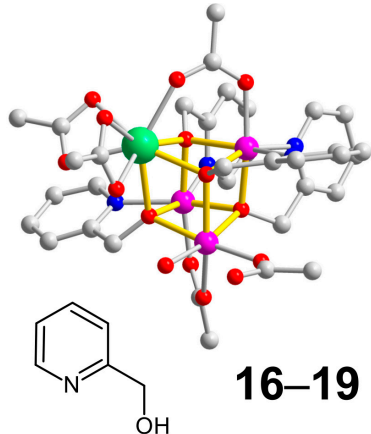

$16-19$

Figure 5. Structures of complexes $9,11,12,14$, and 16-19 with the schemes of respective N-donor ligands. Color scheme: $\mathrm{Co}$, pink; Ln, green; $\mathrm{O}$, red; $\mathrm{N}$, blue; $\mathrm{C}$, grey. $\mathrm{M}-\mathrm{O}-\mathrm{M}$ bonds are highlighted by yellow.

The water oxidation activity of a series of related complexes $\left[\mathrm{Co}_{4}^{\mathrm{III}}{ }_{4} \mathrm{O}_{4}(\mathrm{OAc})_{4}(p \text {-py-X })_{4}\right]$ having para-substituted pyridine $\left(\mathrm{X}=\mathrm{H}, \mathrm{Me}, t-\mathrm{Bu}, \mathrm{OCH}_{3}, \mathrm{Br}, \mathrm{COOCH}_{3}, \mathrm{CN}\right)$ ligands has been reported in 2012 [55]. The nature of the substituent had strong influence on the catalytic activity, with the quantum yields (yield of oxygen based on the photon flux) ranging from $10 \%$ (for $t$ - $\mathrm{Bu}$ ) to $80 \%$ (for $\mathrm{OCH}_{3} ; \mathbf{1 0}$, Table 1), suggesting the molecular nature of catalytically active species. In contrast to most of the other studies, 1:1 mixture of water:acetonitrile was used as a solvent.

Replacement of pyridine with 2-(hydroxymethyl)pyridine ligand $\left(\mathrm{HL}^{5}\right)$, which provides oxygen donor atoms, has led to the formation of cubane complex $\left[\mathrm{Co}_{4}{ }_{4}\left(\mathrm{~L}^{5}\right)_{4}(\mathrm{OAc})_{4}\left(\mathrm{H}_{2} \mathrm{O}\right)_{2}\right](\mathbf{1 1})$ where cobalt has +2 oxidation state (Figure 5), as reported one year after, in 2013 [56]. Another difference from complexes $\mathbf{9}$ and $\mathbf{1 0}$ is the presence of water molecules coordinated to cobalt centers. Water ligands take an important place in the structure of the active centers of PSII (Figure 1), thus the authors indicate that the structure of complex 11 is close to that of the PSII $\mathrm{Mn}_{4} \mathrm{CaO}_{4}$ cubane. Studies of methanol and water solutions of $\mathbf{1 1}$ by ESI-MS and $\mathrm{pH}$-dependent UV-Vis titration disclosed that water ligands remain intact at neutral $\mathrm{pH}$, becoming labile in the alkali media. The presence of labile water represents the main feature of $\mathbf{1 1}$ comparing to $\mathbf{9}$ and $\mathbf{1 0}$, where, in the absence of coordinated water molecules, the protonation-deprotonation may occur at the $\mathrm{Co}_{4} \mathrm{O}_{4}$ core. Dependences of the TON and TOF in the course of catalytic water oxidation on $\mathrm{pH}$ were studied, disclosing that the highest TON of 35 is achieved at $\mathrm{pH} 8$ (11b, Table 1) and the highest TOF of $7.0 \mathrm{~s}^{-1}$ at $\mathrm{pH} 9$ (11c, Table 1). Stability of the core of 11, under catalytic conditions, was investigated by the cyclic voltammetry (CV) experiments, suggesting that the structure of the compound does not undergo degradation. No nanoparticles in the catalytic solutions after $60 \mathrm{~min}$ of visible light irradiation were detected by the DLS method. In the comparative test with $\mathrm{Co}(\mathrm{OAc})_{2}$, formation of the two fractions of nanoparticles (of ca. 5 and $120 \mathrm{~nm}$ 
diameter) under the same conditions was observed. Furthermore, significant difference in the lag times between 11 and $\mathrm{Co}(\mathrm{OAc})_{2}$ catalysts has been observed: While cobalt acetate shows a lag period of $25 \mathrm{~s}$, complex 11 exhibits a much shorter time (ca. $5 \mathrm{~s}$ ), which does not depend on the catalyst concentration.

A series of bi-, tri-, and tetranuclear complexes with pyridine and bipyridine ligands have been tested as the WOCs by Smith et al. in 2014 [57]. While the complexes containing two or three metal centers were found to be catalytically inactive, the tetranuclear compound bearing cubane core $\left[\mathrm{Co}_{4}{ }_{4} \mathrm{O}_{4}(\mathrm{OAc})_{2}(\mathrm{bpy})_{4}\right]\left(\mathrm{ClO}_{4}\right)_{2}(\mathbf{1 2})$ (Figure 5) showed the activity with maximum TOF of $0.05 \mathrm{~s}^{-1}$, achieved at $[11]_{0}=0.02 \mu \mathrm{M}$. At higher concentrations of the catalyst, the TOF drops until $0.02 \mathrm{~s}^{-1}$ (Table 1). The catalyst 9 was also tested under the same conditions, showing a bit higher activity, with a maximum TOF of $0.09 \mathrm{~s}^{-1}$ [57]. The catalytic mixture containing $\mathbf{1 1}$ was analyzed by means of the ESI-MS spectroscopy, revealing the presence of the unaltered complex $\mathbf{1 1}$ at $521 \mathrm{~m} / \mathrm{z}$. The authors interpreted this observation, with the support of $1 \mathrm{H} \mathrm{NMR} \mathrm{data,} \mathrm{as} \mathrm{evidence} \mathrm{that} \mathbf{1 1}$ is a truly molecular WOC. No DLS experiments data were reported.

In 2014, the group of Nocera reinvestigated the water oxidation properties of complexes 9 and 10 [58]. It was demonstrated that the catalytic activity previously associated to the cubane complexes is, in fact, exhibited by the small amounts of $\mathrm{Co}^{2+}$ impurities present in the samples. The ${ }^{1} \mathrm{H}$ NMR spectra of the crude samples of $\mathbf{9}$ and $\mathbf{1 0}$ showed many small peaks. Furthermore, thin layer chromatography disclosed the presence of a few bands in addition to that of the complexes. Purification of the samples using the column chromatography afforded the products with clear ${ }^{1} \mathrm{H}$ NMR spectra. The light-driven water oxidation tests showed that purified samples of 9 possesses ca. five times lower activity than the crude ones (entries 13a and 13b, Table 1). The exact nature of the $\mathrm{Co}^{2+}$ impurities was not identified. It was mentioned that they do not elute on silica and act as a precursor for a heterogeneous oxygen evolving catalyst. Notably, even after purification, complex 9 reveals detectable water oxidation activity (entry $\mathbf{1 3 b}$, Table 1 ).

A series of cubane cobalt $\mathrm{Co}_{4} \mathrm{O}_{4}(\mathbf{1 4})$ and mixed-metal $\mathrm{Co}_{4-x} \mathrm{Ni}_{\mathrm{x}} \mathrm{O}_{4}$ (15) complexes having bipyridine-like ligand was reported in 2017 [59]. The base complex $\left[\mathrm{Co}_{4}{ }_{4}\left(\mathrm{~L}^{6}\right)_{4}(\mathrm{OAc})_{2}\left(\mathrm{H}_{2} \mathrm{O}\right)_{2}\right]\left(\mathrm{ClO}_{4}\right)_{2}$ (14) was prepared starting from the pro-ligand di(2-pyridyl)ketone, which is hydrolyzed to produce the ligand $\mathrm{L}^{6}$ (Figure 5). Complex 14 revealed moderate activity in the water oxidation with maximum TON of 96 (Table 1) at $\mathrm{pH} 8.5$. In general, the catalytic parameters exhibited by $\mathbf{1 4}$ are close to other cobalt cubane complexes (9-13). No nanoparticles formation was observed according to the DLS experiments. The possibility of significant cobalt leaching was rejected by applying the Chelex ${ }^{\circledR}$ resin able to capture free metal ions: only a negligible drop of catalytic activity was observed in the case of 14, while a simple cobalt salt showed $66 \%$ suppression caused by the resin trap. The presence of cobalt in the +2 oxidation state allowed isomorphic substitution of cobalt ions with nickel ones to obtain a series of $\mathrm{Co}_{4-\mathrm{x}} \mathrm{Ni}_{\mathrm{x}} \mathrm{O}_{4}$ cubane complexes with maximum $\mathrm{x}=2.85$ (not including pure nickel compound with $x=4)$, bearing the same structures. The catalytic activity in the water oxidation gradually dropped with the increase of nickel portion, showing the TON and TOF ca. three times lower than for pure cobalt complex. The complex $\mathrm{Ni}_{4} \mathrm{O}_{4}$ did not show any notable catalytic activity under the same conditions [59].

Substitution of one of the metal positions with lanthanide led to a series of $\mathrm{Co}_{3} \mathrm{LnO}_{4}$ cubane complexes $\left[\mathrm{Co}_{3}{ }_{3} \mathrm{Ln}\left(\mathrm{L}^{5}\right)_{4}(\mathrm{OAc})_{5}\left(\mathrm{H}_{2} \mathrm{O}\right)\right]$ (16-19) with 2-(hydroxymethyl)pyridine) ligand $\left(\mathrm{HL}^{5}\right)$ [60]. Compounds of this series were firstly synthesized by mixing cobalt and lanthanide acetates in stoichiometric ratio of 3:1 and characterized by X-ray diffraction [77]. The modified synthetic protocol using Co:Ln ratio of 2.3:1 afforded $\mathrm{Co}_{3} \mathrm{Ln}$ compounds, where $\mathrm{Ln}=\mathrm{Ho}, \mathrm{Er}$, Tm, and $\mathrm{Yb}$ [60]. All complexes show the best performance at $\mathrm{pH}=8$, being slightly less active at $\mathrm{pH}=9$ and considerably less active at $\mathrm{pH}=7$. Erbium complex is the most active with $\mathrm{TON}>200$, while the compound containing thulium shows the weakest results (Table 1). The authors followed a special workflow designed for clear identification of the complexes 16-19 as the water oxidation catalysts. The most important evidence was obtained from the DLS tests (no nanoparticles formation was detected) and trapping of "free" $\mathrm{Co}^{2+}$ ions with EDTA or Chelex ${ }^{\circledR}$ resin (no influence on the catalytic parameters 
observed). Stability of the tetranuclear cores in solution was confirmed by EXAFS, XANES and ESI-MS tests. The coordinated water molecule undergoes rapid exchange with solvent water, as evidenced by the tests in $\mathrm{CD}_{3} \mathrm{CN}$ and $\mathrm{CD}_{3} \mathrm{CN} / \mathrm{D}_{2} \mathrm{O}$ mixture, monitored by FT-IR. The authors account that lanthanide $\mathrm{Ln}^{3+}$ serves as a catalytic promoter, possibly working in analogy to $\mathrm{Ca}^{2+}$ in the natural $\mathrm{CaMn}_{3} \mathrm{O}_{4}$ OEC [60].

Typically, the components of the model catalytic system $[\mathrm{Ru}(\mathrm{bpy})]^{2+} /$ catalyst $/ \mathrm{S}_{2} \mathrm{O}_{8}{ }^{2-}$ are dissolved separately and do not form aggregates in a solution. In such system the electron transfer between the components is strongly influenced by their concentrations. This obstacle could be overcome by joining the photosensitizer, catalyst, and electron acceptor into one module, as it is found in a natural PSII complex. Such an approach is exemplified by the supramolecular assemblies $\left\{\mathrm{Co}_{4} \mathrm{O}_{4}(\mathrm{OAc})_{3}(\mathrm{Py})_{4}\right\}\left\{\left(\mathrm{L}^{7}\right) \mathrm{Ru}(\mathrm{bpy})_{2}\right\}$ and $\left\{\mathrm{Co}_{4} \mathrm{O}_{4}(\mathrm{OAc})_{2}(\mathrm{Py})_{4}\right\}_{2}\left\{\left(\mathrm{~L}^{8}\right) \mathrm{Ru}(\mathrm{bpy})_{2}\right\}_{2}(20$ and 21, respectively, Table 1) ( $\mathrm{L}^{7}=$ bpy-4- $\mathrm{CH}_{3}, 4^{\prime}-\mathrm{COOH} ; \mathrm{L}^{8}=$ bpy-4-COOH, $\left.4^{\prime}-\mathrm{COOH}\right)$ [61], which include two well-studied components: Ruthenium photosensitizer and $\mathrm{Co}_{4} \mathrm{O}_{4}$ cubane WOC (similar to 9). In these compounds, chemical linkage is realized through the modification of bipyridine ligand, attaching to them one or two carboxylic groups (Scheme 4). The integrity of the structures of $\mathbf{2 0}$ and $\mathbf{2 1}$ is supported by ESI-MS and ${ }^{1} \mathrm{H}_{-}{ }^{1} \mathrm{H}$ COSY NMR spectroscopes. Assemblies 20 and 21 have been tested in the light-driven water oxidation (Figure 6) using a rather low concentration of the catalyst of $15 \mu \mathrm{M}$ (calculated per $\mathrm{Co}_{4} \mathrm{O}_{4}$ cubane), showing the TON value of 25 in case of compound 21 (Table 1). The results exhibited by 20 were more modest, with TON of 5 . The authors verified that the catalytic activity of the non-assembled components at the same concentrations is at a negligible level with TON of ca. 2 (20b, Table 1). Furthermore, the dependence of oxygen evolution rate on the catalyst concentration was studied for 20 and $20 \mathrm{~b}$ (the assembly and equimolar mixture, respectively). While the multicomponent mixture $20 \mathrm{~b}$ exhibits saturation at $[20 \mathrm{~b}]_{0}>60 \mu \mathrm{M}$ (with the oxygen evolution rate of $1 \mu \mathrm{M} \mathrm{s}^{-1}$ and TOF of 0.02 $\mathrm{s}^{-1}$ at $\left.[20 \mathrm{~b}]_{0}=60 \mu \mathrm{M}\right)$, the assembly 20 shows linear increase of the reaction rate in the $10<[20]_{0}<$ $100 \mu \mathrm{M}$ concentrations rate, exhibiting a constant TOF of $7 \times 10^{-3} \mathrm{~s}^{-1}$. Monitoring of the reaction mixtures by UV-Vis spectroscopy disclosed a gradual decay of the absorption at $465 \mathrm{~nm}$, attributed to the metal to ligand charge transfer (MLCT) band $[10,32]$ of $\left[\mathrm{Ru}(\mathrm{bpy})_{3}\right]^{2+}$, dropping ca. twice after $60 \mathrm{~min}$. However, the authors note that degradation of the photosensitizer is not a limiting factor because the oxygen evolution stops much earlier, within $30 \mathrm{~min}$ [61]. Since the decoordination of the carboxylic group was suggested to be a part of the water oxidation mechanism, the inactivation pathway may involve irreversible decoordination of the ligands $\mathrm{L}^{7}$ and $\mathrm{L}^{8}$ with following degradation of the supramolecular assembly.

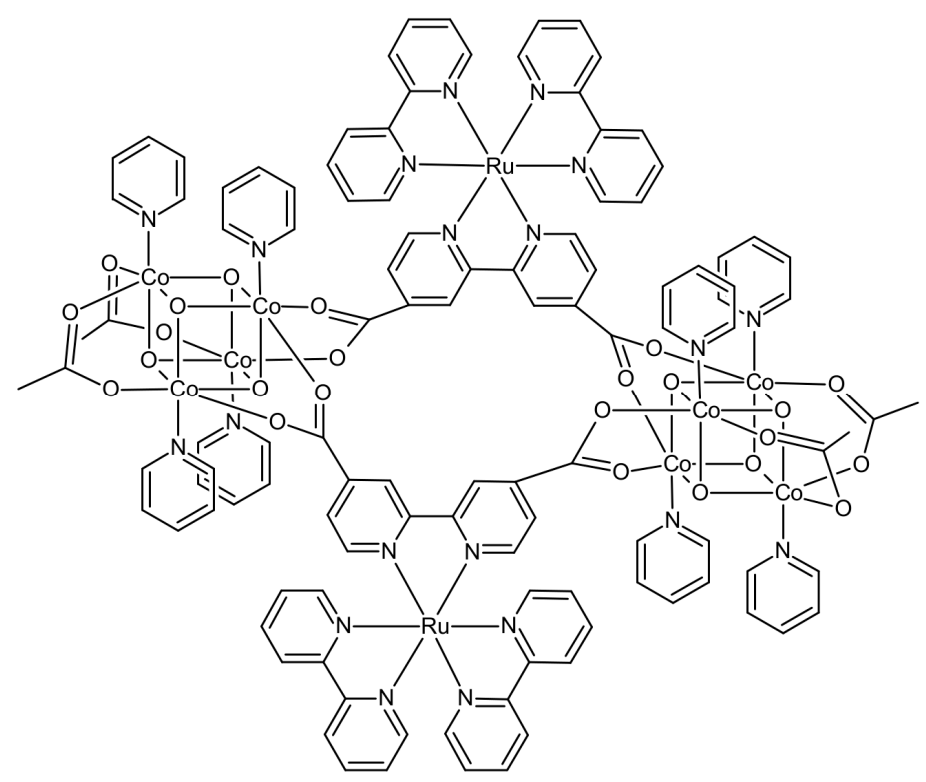

Scheme 4. Schematic representation of assembly 21. 


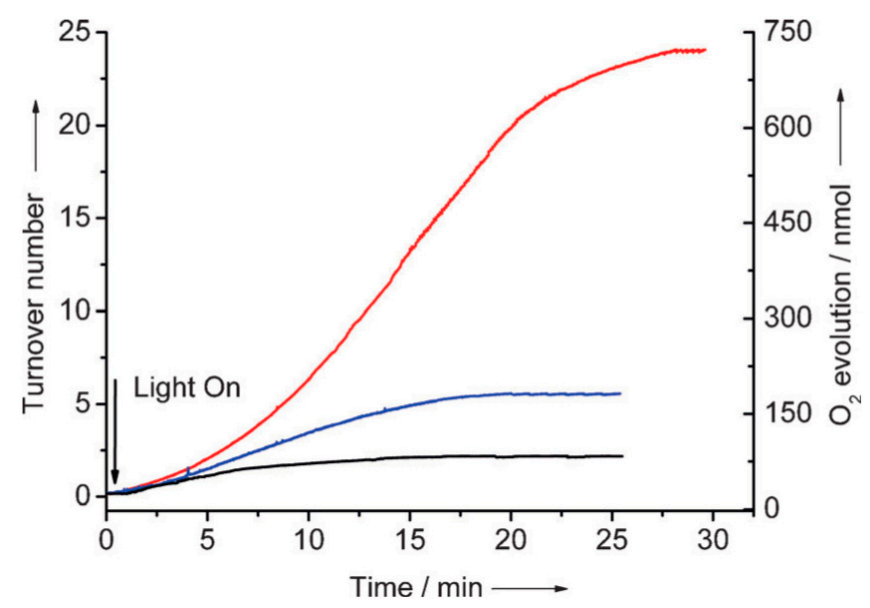

Figure 6. Accumulations of the oxygen in the course of water oxidation catalyzed by assemblies $\left\{\mathrm{Co}_{4} \mathrm{O}_{4}(\mathrm{OAc})_{3}(\mathrm{Py})_{4}\right\}\left\{\left(\mathrm{L}^{7}\right) \mathrm{Ru}(\mathrm{bpy})_{2}\right\}(\mathbf{2 0 a}$, blue line $)$ and $\left\{\mathrm{Co}_{4} \mathrm{O}_{4}(\mathrm{OAc})_{2}(\mathrm{Py})_{4}\right\}_{2}\left\{\left(\mathrm{~L}^{8}\right) \mathrm{Ru}(\mathrm{bpy})_{2}\right\}_{2}(\mathbf{2 1}$, red line), as well as the equimolar mixture of $\left[\mathrm{Co}_{4} \mathrm{O}_{4}(\mathrm{OAc})_{3}(\mathrm{Py})_{4}\right]$ and $\left[\mathrm{Ru}(\mathrm{bpy})_{3}\right] \mathrm{Cl}_{2}$ (20b, black line). Complex $\left[\mathrm{Co}_{4} \mathrm{O}_{4}(\mathrm{OAc})_{3}(\mathrm{Py})_{4}\right]$ is equivalent to 9. Adapted with permission from [61],Wiley, 2014.

\section{Other Tetranuclear Complexes and Complexes of Higher Nuclearity}

The polynuclear all-inorganic complex $\mathrm{Na}_{10}\left[\mathrm{Co}_{4}\left(\mathrm{H}_{2} \mathrm{O}\right)_{2}\left(\mathrm{VW}_{9} \mathrm{O}_{34}\right)_{2}\right]$ (22) bearing polyoxometalate ligand (Figure 7) was tested as a catalyst for the water oxidation under chemical oxidation with $\left[\mathrm{Ru}(\mathrm{bpy})_{3}\right]^{3+}$ as well as the light-driven conditions [62]. Chemical oxidation revealed exceptionally high TOF values ranging from 1600 to $2200 \mathrm{~s}^{-1}$ (adjusted for four cobalt centers in 22), supported by TONs up to 75 (22a, Table 1). With such a high TOF the reaction completes within $1 \mathrm{~s}$. In contrast, photocatalytic oxidation with in situ generated $\left[\mathrm{Ru}(\mathrm{bpy})_{3}\right]^{3+}$ revealed the lower TOFs of ca. $4 \mathrm{~s}^{-1}(\mathbf{2 2 b})$, but higher TON of 742 (or even up to 4210 for the lowest [22] , Table 1). The quantum efficiency of the catalytic system is at rather high level, up to $68 \%$ (for $[22]_{0}=6 \mu \mathrm{M}$ ). The integrity of the catalyst during the catalysis was monitored by means of UV-Vis and ${ }^{51}$ V NMR spectroscopes, which suggested no changes in the structure of 22. The DLS experiments showed no presence of nanoparticles after both chemical and light-driven oxidations catalyzed by $\mathbf{2 2}$. The comparative test using $\mathrm{Co}\left(\mathrm{NO}_{3}\right)_{2}$ as catalyst revealed formation of $\mathrm{CoO}_{x}$ nanoparticles with the radius of $220 \mathrm{~nm}$ [62].

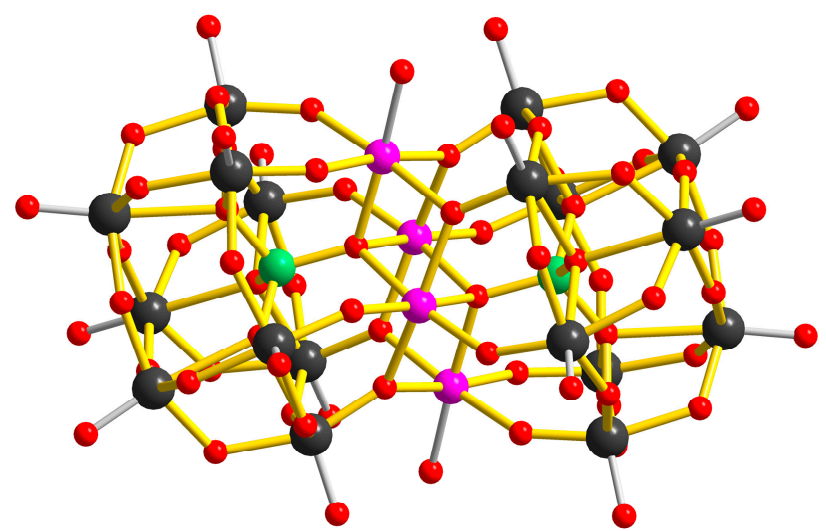

Figure 7. Structure of the anion of the compound 22. Color scheme: Co, pink; V, green; W, black; O, red; $\mathrm{M}-\mathrm{O}-\mathrm{M}$ bonds are highlighted by yellow.

Two coordination compounds $\left[\mathrm{Co}_{4}\left(\mathrm{H}_{2} \mathrm{O}\right)_{4}\left(\mathrm{HL}^{9}\right)_{2}\left(\mathrm{~L}^{9}\right)_{2}\right]$ and $\mathrm{K}_{12}\left[\mathrm{Co}\left(\mathrm{L}^{9}\right)\right]_{6} \quad(23$ and 24, respectively) bearing tetra- and hexanuclear structures were prepared starting from $\mathrm{N}$-(phosphonomethyl)iminodiacetic acid $\left(\mathrm{H}_{4} \mathrm{~L}^{9}\right)$ as pro-ligand (Figure 8) and cobalt chloride or acetate as a metal source, respectively $[63,64]$. Complex 23 disclosed TONs up to 662 (Table 1) in the 
light-driven water oxidation. The standard set of experiments (UV-Vis and comparative DLS tests of 23 and cobalt nitrate pre-catalyst) were applied to confirm that no nanoparticles were formed after light-driven water oxidation using catalyst 23 [63]. Moreover, a set of extractions with following ICP-MS (inductively coupled plasma mass spectrometry) and CAdSV (catalytic adsorptive stripping voltammetry) experiments were performed, indicating that less than $0.35 \%$ of catalyst 23 released free $\mathrm{Co}^{2+}$ ions in the buffer solution. One may notice that cobalt nitrate, as pre-catalyst under the same conditions, showed TON of 150 (for $\left[\mathrm{Co}^{2+}\right]_{0}=2 \mu \mathrm{M}$ ). This value is even higher than that exhibited by catalyst 23 if adjusted for six cobalt atoms in its molecule ( $\mathrm{TON}=110)$.

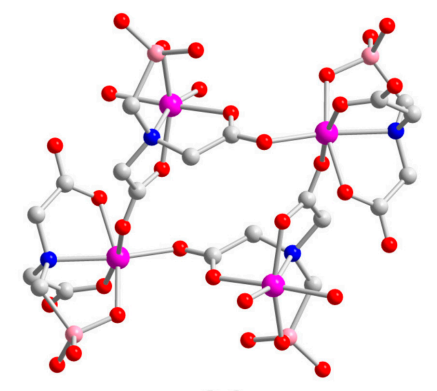

23<smiles>O=C(O)CN(CC(=O)O)CP(=O)(O)O</smiles>

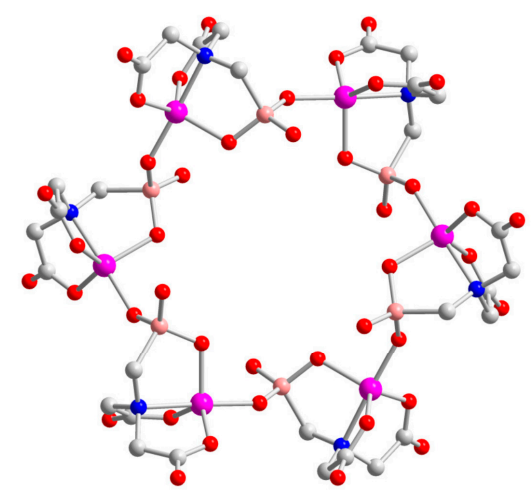

24

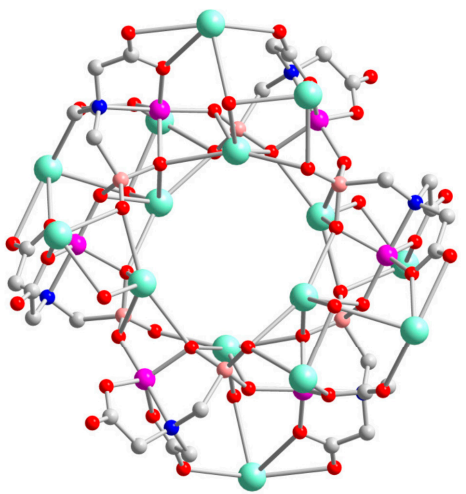

Figure 8. Structure of complexes 23 and 24. Color scheme: Co, pink; K, pale green; O, red; N, blue; $\mathrm{P}$, pale pink. Structure $\mathbf{2 4}$ is presented in two views, without (left) and with (right) nearest potassium atoms.

The hexanuclear complex 24 features amongst the highest values of the TOF reported to date (162.6 s ${ }^{-1}$ per cobalt atom) for the light-driven water oxidation (Table 1) [64]. The use of perchlorate salt of the ruthenium photosensitizer is crucial since the chloride salt shows a ca. 4.7 times lower reaction rate (24a, Table 1). The maximum quantum efficiency was found to be $62.6 \%$. Considering such a high parameters, it was important to establish the origin of the catalytically active species. The comparative test with $\mathrm{Co}(\mathrm{OAc})_{2}$ revealed that the latter shows large lag period of $30 \mathrm{~s}$ at $5 \mu \mathrm{M}$, while catalyst 24 shows no or negligible lag time. Furthermore, the chelation experiment using three equivalents of EDTA revealed no influence on the activity of 24, while the oxygen evolution catalyzed by cobalt acetate was ca. 50\% suppressed (both catalysts were at $7 \mu \mathrm{M}$ initial concentration). The precipitate recovered after the reaction was studied by X-ray photoelectron spectroscopy (XPS) and was recognized as the authentic complex $\mathbf{2 4}$. The evidence reported by the authors looks convincing, although absence of the DLS experiment is an essential drawback of the investigation. The proposed mechanism of water oxidation involves participation of a single cobalt center only, what is in agreement with the first-order dependence of the reaction rate on the concentration of 24 (for [24] $]_{0}<5 \mu \mathrm{M}$ ) [64]. Kinetic isotope effect (KIE) $k_{H} / k_{D}$ between parallel reactions in normal and deuterated water was found to be 2.53 , suggesting that catalyst 24 acts via the WNA mechanism, where a dioxygen molecule 
is constructed by the oxygen atoms from metal-oxo species and water molecule [7]. This value of KIE is very close to that reported (2.45) for ruthenium complex $[\mathrm{Ru}(\mathrm{bda}) \mathrm{bpb}]_{3}{ }^{+}$having cyclic structure $\left(\mathrm{H}_{2} \mathrm{bda}\right.$ $=2,2^{\prime}$-bipyridine-6,6'-dicarboxylic acid; $\mathrm{bpb}=1,4$-Bis(pyrid-3-yl)benzene) believed to operate via the WNA pathway [78]. Unfortunately, in the case of $\mathbf{2 4}$, no ${ }^{18} \mathrm{O}$-labeling experiments were performed to confirm the attribution of the mechanism type.

The authors presented the structure of 24 as the open $\mathrm{Co}_{6}$ ring (Figure 8, bottom-left) [62]. Such architecture could be rather labile in solution, especially under conditions of oxidative catalysis. Thus, the following questions appear: (1) Why is this compound is stable? (2) Why does it show such a high catalytic parameters? For instance, complex $\mathbf{2 3}$ is built using the same ligand (Figure 8) and does not possess water oxidation properties drastically different from those already reported (Table 1 ). The answer to both these questions could be found in the supramolecular structure of 24 (Figure 8, botom-right). The six-membered $\mathrm{Co}_{6}$ ring is strengthened by potassium atoms, coordinating free oxygen atoms of the ligand, as well as numerous water molecules. Here, one may see two opportunities for the enhancement of the water oxidation reactions. At first, potassium may influence the redox potential of the cobalt centers, as it happens in the $\mathrm{Ca}_{3} \mathrm{Mn}_{4} \mathrm{O}_{4}$ center of PSII and in the respective model complexes. Furthermore, recent experiments demonstrate that hydrogen bonding around the OEC in PSII is crucial for the water oxidation activity. The complex network of hydrogen bonds, formed by the water molecules coordinated by potassium atoms in the structure of $\mathbf{2 4}$, may exist in a solution and be of great importance for successful water splitting process.

Another example of an all-inorganic compound of cobalt is the heptanuclear complex $\mathrm{Na}_{12}\left[\left\{\mathrm{Co}_{7} \mathrm{As}_{6} \mathrm{O}_{9}(\mathrm{OH})_{6}\right\}\left(\mathrm{SiW}_{9} \mathrm{O}_{34}\right)_{2}\right]$ (25) [65]. The structure of 25 (Figure 9) resembles that of 22. In general, the catalytic activity of $\mathbf{2 5}$ in the water photocatalytic oxidation is in the range typically exhibited by the other cobalt complexes of lower nuclearity (Table 1). DLS measurements showed no nanoparticles after the light-driven reaction, while in comparative test with $\mathrm{Co}\left(\mathrm{NO}_{3}\right)_{2}$ as catalyst, the presence of nanoparticles of ca. $190 \mathrm{~nm}$ in diameter were reported.

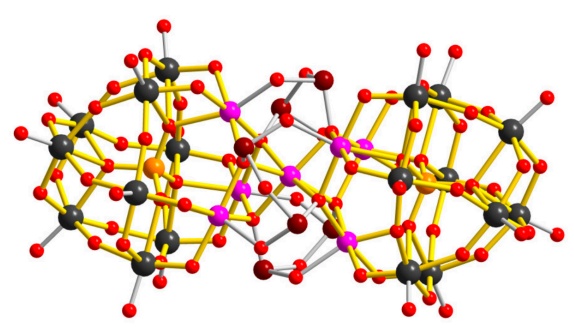

25

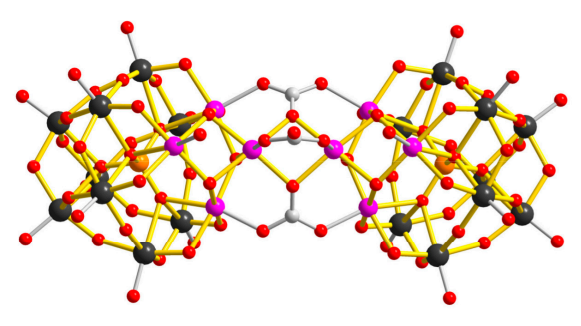

27
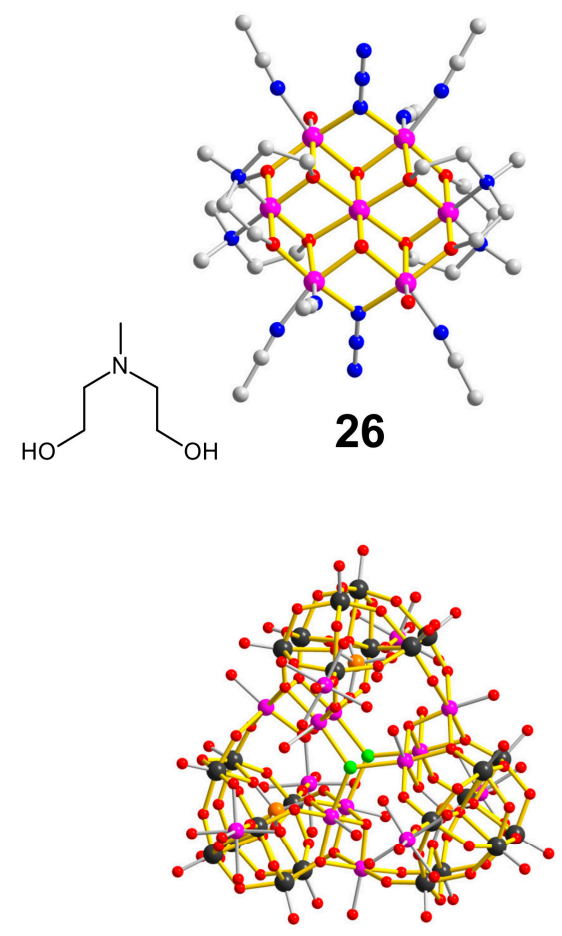

29

Figure 9. Structures of complexes 25-27, and 29 (for 25, 27, and 29 cationic counterions are omitted). Color scheme: $\mathrm{Co}$, pink; W, black; $\mathrm{As}$, dark red; $\mathrm{Si}$, orange; $\mathrm{Cl}$, green; $\mathrm{O}$, red; $\mathrm{N}$, blue. 
The structure of the heptanuclear mixed-valence complex $\left[\mathrm{Co}_{5} \mathrm{II}_{5} \mathrm{CoII}_{2}(\mathrm{mdea})_{4}\left(\mathrm{~N}_{3}\right)_{2}\left(\mathrm{CH}_{3} \mathrm{CN}\right)_{6}\right.$ $\left.(\mathrm{OH})_{2}\left(\mathrm{H}_{2} \mathrm{O}\right)_{2}\right]\left(\mathrm{ClO}_{4}\right)_{4}(26)\left(\mathrm{H}_{2}\right.$ mdea $=\mathrm{N}$-methyldiethanolamine $)$ is based on the so-called Anderson structure type (Figure 9) [66]. Oxygen evolution was studied for chloride and perchlorate salts of ruthenium photosensitizer, showing that the latter produces higher TON values (26b and $\mathbf{2 6 c}$, respectively; Table 1). Using the chelating agents (bpy and EDTA), the decay of the oxygen evolution was observed when taken in equimolar ratio with the pre-catalyst 26. The ESI-MS spectra indicated that 26 undergoes fragmentation in water solution since no peak attributable to $\mathrm{Co}_{7}$ cluster was detected.

The octanuclear cobalt complex $\left.\mathrm{K}_{8} \mathrm{Na}_{8}\left[\mathrm{Co}_{8}(\mathrm{OH})_{6}\left(\mathrm{H}_{2} \mathrm{O}\right)_{2}\left(\mathrm{CO}_{3}\right)_{3} \mathrm{SiW}_{9} \mathrm{O}_{34}\right)_{2}\right]$ (27) containing bulky polyoxometalate ligand (the same as in 25) has been described [79] and studied [67] as catalyst for water oxidation. An interesting feature of the structure of $\mathbf{2 7}$ is the presence of carbonate ligands (Figure 9). Complex 27 acts as a catalyst for water oxidation, showing the highest efficiency at $\mathrm{pH} 9$ with the highest TON of 1435 and highest TOF of $10 \mathrm{~s}^{-1}$ (27b, Table 1). According to the DLS experiments, no nanoparticles are formed from 27 during the catalytic reaction. The comparative test with $2 \mu \mathrm{M}$ of $\mathrm{Co}\left(\mathrm{NO}_{3}\right)_{2}$ revealed nanoparticles with diameter of $78 \mathrm{~nm}$. FT-IR and UV-Vis spectroscopes also evidenced that the complex keeps its integrity after the catalysis. ESI-MS data are also provided, but the spectra appear to be too noisy (low overall intensity) to use them to make definite conclusions.

A series of high-nuclear cobalt complexes with polyoxometalate capping ligands $\mathrm{K}_{16}\left[\mathrm{Co}_{9}\left(\mathrm{H}_{2} \mathrm{O}\right)_{6}\right.$ $\left.(\mathrm{OH})_{3}\left(\mathrm{PW}_{9} \mathrm{O}_{34}\right)_{3}\right] \quad$ (28) [80], $\mathrm{Na}_{5}\left[\mathrm{Co}_{6}\left(\mathrm{H}_{2} \mathrm{O}\right)_{30}\left\{\mathrm{Co}_{9} \mathrm{Cl}_{2}(\mathrm{OH})_{3}\left(\mathrm{H}_{2} \mathrm{O}\right)_{9}\left(\mathrm{SiW}_{8} \mathrm{O}_{31}\right)_{3}\right\}\right]$ (29) [81] and $\mathrm{Na}_{22} \mathrm{Rb}_{6}\left[\left\{\mathrm{Co}_{4}(\mathrm{OH})_{3} \mathrm{PO}_{4}\right\}_{4}\left(\mathrm{PW}_{9} \mathrm{O}_{34}\right)_{4}\right]$ (30) [82] have been recently tested as catalysts for light-driven water oxidation [68]. Compounds 28-30 obey rather complicated architectures (complex $\mathbf{2 9}$ is depicted at Figure 9 as an example). The electron transfer between complexes 28-30 and photogenerated $\left[\mathrm{Ru}(\mathrm{bpy})_{3}\right]^{3+}$ has been studied in detail. No lag period has been detected in all cases. EXAFS and XANES experiments suggested the existence of water exchange processes with small alterations of the complexes cores, without their degradation. The catalytic parameters exhibited by 28-30 are modest with TONs not exceeding 105 (for [29 $]_{0}=1.27 \mu \mathrm{M}$ ). In general, Complex 29 shows better performance among this series. The authors note that the structure of $\mathbf{2 9}$, containing 39 coordinated terminal water molecules, may facilitate its WOC activity [68].

\section{Concluding Remarks}

The field of the cobalt catalyzed water oxidation under visible light irradiation has received much attention in recent years. Pronounced activity of many molecular catalysts demonstrates great potential towards the construction of modular artificial water splitting systems. The TOF values exhibited by some of the catalytic systems approach those exhibited by the PSII system. However, one should always keep in mind that PSII and artificial systems operate at quite different conditions, thus any direct comparison of their parameters should be done with care. Furthermore, depending on the rate-limiting step of the catalytic reaction, the TOF may characterize, for instance, charge transfer between photosensitizer and catalyst, but not the rate of the dioxygen formation by the catalyst.

Discrimination of the true molecular (homogeneous) and heterogeneous systems should be always conducted to ensure that the molecular catalyst keeps its integrity and/or does not undergo heterogenization during the catalysis. The simplest methods involve comparative tests using cobalt salts with the same concentrations as that of the catalyst studied. Chelation experiments employing EDTA or bipyridine additives can provide fast evidence for the metal ions leaching. Purification of the sample from the metal impurities can also play an important role, as demonstrated by the examples of $\mathrm{Co}_{4} \mathrm{O}_{4}$ cubane complexes (9-13, Table 1). The typical instrumental method for nanoparticles detection is the dynamic light scattering (DLS), which is routinely applied in most of the literature reports discussed in the present review. However, one should remember that DLS has its own limitations and should not be used as a single method (see samples $7 \mathbf{a}$ and $7 \mathbf{b}$ as a representative example). Even the design of the experimental setup could have strong influence on the DLS results; for example, the use of magnetic stirring bars may complicate detection of nanoparticles possessing ferromagnetic properties. 
Catalytic activity depends on many parameters, often implicit ones. For instance, the catalytic parameters exhibited by the systems containing $\left[\mathrm{Ru}(\mathrm{bpy})_{3}\right]\left(\mathrm{ClO}_{4}\right)_{2}$ as photosensitizer are systematically higher than those obtained for using $\left[\mathrm{Ru}(\mathrm{bpy})_{3}\right] \mathrm{Cl}_{2}$. Thus, careful documentation of the experimental conditions is of exceptional significance for further analysis.

In spite of great efforts towards the study of the catalytic activity and verification of the catalyst stability, the reported reaction mechanisms are typically limited to general descriptions of charge transfers between photosensitizer and sacrificial electron acceptor, while attempts to study the mechanism of action of the WOC itself are scarce.

As a final remark, the use of cheap and abundant metals, such as cobalt, allows for the construction of highly efficient water oxidation catalysts. A special interest is in regards the bioinspired heterometallic complexes involving polynuclear cobalt core with attached redox-inactive metals. The exact mechanisms of many known artificial water oxidation systems are still unexplored and, beyond any doubt, further synthetic and catalytic efforts are required to establish structure-properties correlations towards practically feasible artificial photosynthesis.

Author Contributions: N.D.S. and O.V.N. contributed equally.

Funding: This work was supported by the Foundation for Science and Technology (FCT), Portugal (projects UID/QUI/00100/2013 and PTDC/QEQ-QIN/3967/2014, fellowships SFRH/BPD/99533/2014 and SFRH/BPD/63710/2009).

Conflicts of Interest: The authors declare no conflicts.

\section{References}

1. Chu, S.; Majumdar, A. Opportunities and challenges for a sustainable energy future. Nature 2012, 488, 294-303. [CrossRef] [PubMed]

2. Lewis, N.S.; Nocera, D.G. Powering the planet: Chemical challenges in solar energy utilization. Proc. Natl. Acad. Sci. USA 2006, 103, 15729-15735. [CrossRef] [PubMed]

3. Kopp, G.; Lean, J.L. A new, lower value of total solar irradiance: Evidence and climate significance. Geophys. Res. Lett. 2011, 38. [CrossRef]

4. Berardi, S.; Drouet, S.; Francas, L.; Gimbert-Surinach, C.; Guttentag, M.; Richmond, C.; Stoll, T.; Llobet, A. Molecular artificial photosynthesis. Chem. Soc. Rev. 2014, 43, 7501-7519. [CrossRef] [PubMed]

5. Pantazis, D.A. Missing Pieces in the Puzzle of Biological Water Oxidation. ACS Catal. 2018, 8, 9477-9507. [CrossRef]

6. Shamsipur, M.; Pashabadi, A. Latest advances in PSII features and mechanism of water oxidation. Coord. Chem. Rev. 2018, 374, 153-172. [CrossRef]

7. Garrido-Barros, P.; Gimbert-Surinach, C.; Matheu, R.; Sala, X.; Llobet, A. How to make an efficient and robust molecular catalyst for water oxidation. Chem. Soc. Rev. 2017, 46, 6088-6098. [CrossRef]

8. Najafpour, M.M.; Renger, G.; Holynska, M.; Moghaddam, A.N.; Aro, E.-M.; Carpentier, R.; Nishihara, H.; Eaton-Rye, J.J.; Shen, J.-R.; Allakhverdiev, S.I. Manganese Compounds as Water-Oxidizing Catalysts: From the Natural Water-Oxidizing Complex to Nanosized Manganese Oxide Structures. Chem. Rev. 2016, 116, 2886-2936. [CrossRef]

9. Yano, J.; Yachandra, V. $\mathrm{Mn}_{4} \mathrm{Ca}$ Cluster in Photosynthesis: Where and How Water is Oxidized to Dioxygen. Chem. Rev. 2014, 114, 4175-4205. [CrossRef]

10. Karkas, M.D.; Verho, O.; Johnston, E.V.; Akermark, B. Artificial Photosynthesis: Molecular Systems for Catalytic Water Oxidation. Chem. Rev. 2014, 114, 11863-12001. [CrossRef]

11. Miyoshi, A.; Nishioka, S.; Maeda, K. Water Splitting on Rutile $\mathrm{TiO}_{2}$-Based Photocatalysts. Chem. Eur. J. 2018. [CrossRef] [PubMed]

12. Brennaman, M.K.; Dillon, R.J; Alibabaei, L.; Gish, M.K.; Dares, C.J; Ashford, D.L.; House, R.L.; Meyer, G.J; Papanikolas, J.M.; Meyer, T.J. Finding the Way to Solar Fuels with Dye-Sensitized Photoelectrosynthesis Cells. J. Am. Chem. Soc. 2016, 138, 13085-13102. [CrossRef] [PubMed]

13. Sauer, K. A Role for Manganese in Oxygen Evolution in Photosynthesis. Acc. Chem. Res. 1980, 13, 249-256. [CrossRef] 
14. Zhang, M.; Bommer, M.; Chatterjee, R.; Hussein, R.; Yano, J.; Dau, H.; Kern, J.; Dobbek, H.; Zouni, A. Structural insights into the light-driven auto-assembly process of the water oxidizing $\mathrm{Mn}_{4} \mathrm{CaO}_{5}$-cluster in photosystem II. eLife 2017, 6, e26933. [CrossRef] [PubMed]

15. Shen, J.-R. The Structure of Photosystem II and the Mechanism of Water Oxidation in Photosynthesis. Ann. Rev. Plant Biol. 2015, 66, 23-48. [CrossRef] [PubMed]

16. Zouni, A.; Witt, H.T.; Kern, J.; Fromme, P.; Krauss, N.; Saenger, W.; Orth, P. Crystal structure of photosystem II from Synechococcus elongatus at 3.8 angstrom resolution. Nature 2001, 409, 739-743. [CrossRef] [PubMed]

17. Ferreira, K.N.; Iverson, T.M.; Maghlaoui, K.; Barber, J.; Iwata, S. Architecture of the photosynthetic oxygen-evolving center. Science 2004, 303, 1831-1838. [CrossRef]

18. Loll, B.; Kern, J.; Saenger, W.; Zouni, A.; Biesiadka, J. Towards complete cofactor arrangement in the 3.0 angstrom resolution structure of photosystem II. Nature 2005, 438, 1040-1044. [CrossRef]

19. Umena, Y.; Kawakami, K.; Shen, J.R.; Kamiya, N. Crystal structure of oxygen-evolving photosystem II at a resolution of 1.9 angstrom. Nature 2011, 473, 55-61. [CrossRef]

20. Suga, M.; Akita, F.; Sugahara, M.; Kubo, M.; Nakajima, Y.; Nakane, T.; Yamashita, K.; Umena, Y.; Nakabayashi, M.; Yamane, T.; et al. Light-induced structural changes and the site of $\mathrm{O}=\mathrm{O}$ bond formation in PSII caught by XFEL. Nature 2017, 543, 131. [CrossRef]

21. Retegan, M.; Krewald, V.; Mamedov, F.; Neese, F.; Lubitz, W.; Cox, N.; Pantazis, D.A. A five-coordinate $\mathrm{Mn}(\mathrm{IV})$ intermediate in biological water oxidation: Spectroscopic signature and a pivot mechanism for water binding. Chem. Sci. 2016, 7, 72-84. [CrossRef] [PubMed]

22. Young, I.D.; Ibrahim, M.; Chatterjee, R.; Gul, S.; Fuller, F.D.; Koroidov, S.; Brewster, A.S.; Tran, R.; Alonso-Mori, R.; Kroll, T.; et al. Structure of photosystem II and substrate binding at room temperature. Nature 2016, 540, 453. [CrossRef] [PubMed]

23. Bao, H.; Burnap, R.L. Photoactivation: The Light-Driven Assembly of the Water Oxidation Complex of Photosystem II. Front. Plant Sci. 2016, 7. [CrossRef] [PubMed]

24. Yocum, C.F. The calcium and chloride requirements of the $\mathrm{O}_{2}$ evolving complex. Coordi.Chem. Rev. 2008, 252, 296-305. [CrossRef]

25. Zhang, C.; Chen, C.; Dong, H.; Shen, J.-R.; Dau, H.; Zhao, J. A synthetic $\mathrm{Mn}_{4}$ Ca-cluster mimicking the oxygen-evolving center of photosynthesis. Science 2015, 348, 690-693. [CrossRef] [PubMed]

26. Kanady, J.S.; Tsui, E.Y.; Day, M.W.; Agapie, T. A Synthetic Model of the $\mathrm{Mn}_{3} \mathrm{Ca}$ Subsite of the Oxygen-Evolving Complex in Photosystem II. Science 2011, 333, 733-736. [CrossRef]

27. Tsui, E.Y.; Tran, R.; Yano, J.; Agapie, T. Redox-inactive metals modulate the reduction potential in heterometallic manganese-oxido clusters. Nat. Chem. 2013, 5, 293-299. [CrossRef]

28. Chen, C.G.; Kazimir, J.; Cheniae, G.M. Calcium Modulates the Photoassembly of Photosystem-II $\mathrm{Mn}_{4}$-Clusters by Preventing Ligation of Nonfunctional High-Valency States of Manganese. Biochemistry 1995, 34, 13511-13526. [CrossRef]

29. Buvaylo, E.A.; Nesterova, O.V.; Kokozay, V.N.; Vassilyeva, O.Y.; Skelton, B.W.; Boca, R.; Nesterov, D.S. Discussion of Planarity of Molecular Structures Using Novel Pentanuclear Cu/Ni Complexes as an Example. Cryst. Grow. Des. 2012, 12, 3200-3208. [CrossRef]

30. Groom, C.R.; Bruno, I.J.; Lightfoot, M.P.; Ward, S.C. The Cambridge Structural Database. Acta Cryst. B 2016, 72, 171-179. [CrossRef]

31. Puntoriero, F.; Sartorel, A.; Orlandi, M.; La Ganga, G.; Serroni, S.; Bonchio, M.; Scandola, F.; Campagna, S. Photoinduced water oxidation using dendrimeric $\mathrm{Ru}(\mathrm{II})$ complexes as photosensitizers. Coord. Chem. Rev. 2011, 255, 2594-2601. [CrossRef]

32. Prier, C.K.; Rankic, D.A.; MacMillan, D.W.C. Visible Light Photoredox Catalysis with Transition Metal Complexes: Applications in Organic Synthesis. Chem. Rev. 2013, 113, 5322-5363. [CrossRef] [PubMed]

33. Bolletta, F.; Juris, A.; Maestri, M.; Sandrini, D. Quantum Yield of Formation of the Lowest Excited-State of $\mathrm{Ru}(\mathrm{bpy})_{3}{ }^{2+}$ and $\mathrm{Ru}(\mathrm{phen})_{3}{ }^{2+}$. Inorg. Chim. Acta Lett. 1980, 44, L175-L176. [CrossRef]

34. Blakemore, J.D.; Crabtree, R.H.; Brudvig, G.W. Molecular Catalysts for Water Oxidation. Chem. Rev. 2015, 115, 12974-13005. [CrossRef] [PubMed]

35. Karkas, M.D.; Akermark, B. Water oxidation using earth-abundant transition metal catalysts: Opportunities and challenges. Dalton Trans. 2016, 45, 14421-14461. [CrossRef] [PubMed]

36. Singh, A.; Spiccia, L. Water oxidation catalysts based on abundant 1st row transition metals. Coord. Chem. Rev. 2013, 257, 2607-2622. [CrossRef] 
37. Han, Q.; Ding, Y. Recent advances in the field of light-driven water oxidation catalyzed by transition-metal substituted polyoxometalates. Dalton Trans. 2018, 47, 8180-8188. [CrossRef]

38. Wenger, O.S. Photoactive Complexes with Earth-Abundant Metals. J. Am. Chem. Soc. 2018. [CrossRef]

39. Artero, V.; Chavarot-Kerlidou, M.; Fontecave, M. Splitting Water with Cobalt. Angew. Chem. Int. Ed. 2011, 50, 7238-7266. [CrossRef]

40. Kanan, M.W.; Nocera, D.G. In situ formation of an oxygen-evolving catalyst in neutral water containing phosphate and $\mathrm{Co}^{2+}$. Science 2008, 321, 1072-1075. [CrossRef]

41. Jiao, F.; Frei, H. Nanostructured Cobalt Oxide Clusters in Mesoporous Silica as Efficient Oxygen-Evolving Catalysts. Angew. Chem. Int. Ed. 2009, 48, 1841-1844. [CrossRef] [PubMed]

42. Dismukes, G.C.; Brimblecombe, R.; Felton, G.A.N.; Pryadun, R.S.; Sheats, J.E.; Spiccia, L.; Swiegers, G.F. Development of Bioinspired $\mathrm{Mn}_{4} \mathrm{O}_{4}$-Cubane Water Oxidation Catalysts: Lessons from Photosynthesis. Acc. Chem. Res. 2009, 42, 1935-1943. [CrossRef] [PubMed]

43. Yin, Q.; Tan, J.M.; Besson, C.; Geletii, Y.V.; Musaev, D.G.; Kuznetsov, A.E.; Luo, Z.; Hardcastle, K.I.; Hill, C.L. A Fast Soluble Carbon-Free Molecular Water Oxidation Catalyst Based on Abundant Metals. Science 2010, 328, 342-345. [CrossRef] [PubMed]

44. Huang, Z.; Luo, Z.; Geletii, Y.V.; Vickers, J.W.; Yin, Q.; Wu, D.; Hou, Y.; Ding, Y.; Song, J.; Musaev, D.G.; et al. Efficient Light-Driven Carbon-Free Cobalt-Based Molecular Catalyst for Water Oxidation. J. Am. Chem. Soc. 2011, 133, 2068-2071. [CrossRef] [PubMed]

45. Stracke, J.J.; Finke, R.G. Electrocatalytic Water Oxidation Beginning with the Cobalt Polyoxometalate $\mathrm{Co}_{4}\left(\mathrm{H}_{2} \mathrm{O}\right)_{2}\left(\mathrm{PW}_{9} \mathrm{O}_{34}\right)_{2}{ }^{10-}$ : Identification of Heterogeneous $\mathrm{CoO}_{\mathrm{x}}$ as the Dominant Catalyst. J. Am. Chem. Soc. 2011, 133, 14872-14875. [CrossRef] [PubMed]

46. Fu, S.; Liu, Y.; Ding, Y.; Du, X.; Song, F.; Xiang, R.; Ma, B. A mononuclear cobalt complex with an organic ligand acting as a precatalyst for efficient visible light-driven water oxidation. Chem. Commun. 2014, 50, 2167-2169. [CrossRef] [PubMed]

47. Nakazono, T.; Parent, A.R.; Sakai, K. Cobalt porphyrins as homogeneous catalysts for water oxidation. Chem. Commun. 2013, 49, 6325-6327. [CrossRef]

48. Leung, C.-F.; Ng, S.-M.; Ko, C.-C.; Man, W.-L.; Wu, J.; Chen, L.; Lau, T.-C. A cobalt(II) quaterpyridine complex as a visible light-driven catalyst for both water oxidation and reduction. Energ. Environ. Sci. 2012, 5, 7903-7907. [CrossRef]

49. Hong, D.; Jung, J.; Park, J.; Yamada, Y.; Suenobu, T.; Lee, Y.M.; Nam, W.; Fukuzumi, S. Water-soluble mononuclear cobalt complexes with organic ligands acting as precatalysts for efficient photocatalytic water oxidation. Energ. Environ. Sci. 2012, 5, 7606-7616. [CrossRef]

50. Ishizuka, T.; Watanabe, A.; Kotani, H.; Hong, D.; Satonaka, K.; Wada, T.; Shiota, Y.; Yoshizawa, K.; Ohara, K.; Yamaguchi, K.; et al. Homogeneous Photocatalytic Water Oxidation with a Dinuclear Co ${ }^{\text {III }}$ Pyridylmethylamine Complex. Inorg. Chem. 2016, 55, 1154-1164. [CrossRef]

51. Wang, H.-Y.; Mijangos, E.; Ott, S.; Thapper, A. Water Oxidation Catalyzed by a Dinuclear Cobalt-Polypyridine Complex. Angew. Chem. Int. Ed. 2014, 53, 14499-14502. [CrossRef] [PubMed]

52. Wang, J.-W.; Sahoo, P.; Lu, T.-B. Reinvestigation of Water Oxidation Catalyzed by a Dinuclear Cobalt Polypyridine Complex: Identification of $\mathrm{CoO}_{x}$ as a Real Heterogeneous Catalyst. ACS Catal. 2016, 6, 5062-5068. [CrossRef]

53. Lin, J.; Ma, B.; Chen, M.; Ding, Y. Water oxidation catalytic ability of polypyridine complex containing a $\mu-\mathrm{OH}, \mu-\mathrm{O}_{2}$ dicobalt(III) core. Chin. J. Catal. 2018, 39, 463-471. [CrossRef]

54. McCool, N.S.; Robinson, D.M.; Sheats, J.E.; Dismukes, G.C. A Co $\mathrm{O}_{4}$ "Cubane" Water Oxidation Catalyst Inspired by Photosynthesis. J. Am. Chem. Soc. 2011, 133, 11446-11449. [CrossRef] [PubMed]

55. Berardi, S.; La Ganga, G.; Natali, M.; Bazzan, I.; Puntoriero, F.; Sartorel, A.; Scandola, F.; Campagna, S.; Bonchio, M. Photocatalytic Water Oxidation: Tuning Light-Induced Electron Transfer by Molecular $\mathrm{Co}_{4} \mathrm{O}_{4}$ Cores. J. Am. Chem. Soc. 2012, 134, 11104-11107. [CrossRef] [PubMed]

56. Evangelisti, F.; Guettinger, R.; More, R.; Luber, S.; Patzke, G.R. Closer to Photosystem II: $\mathrm{A} \mathrm{Co}_{4} \mathrm{O}_{4} \mathrm{Cubane}$ Catalyst with Flexible Ligand Architecture. J. Am. Chem. Soc. 2013, 135, 18734-18737. [CrossRef] [PubMed]

57. Smith, P.F.; Kaplan, C.; Sheats, J.E.; Robinson, D.M.; McCool, N.S.; Mezle, N.; Dismukes, G.C. What Determines Catalyst Functionality in Molecular Water Oxidation? Dependence on Ligands and Metal Nuclearity in Cobalt Clusters. Inorg. Chem. 2014, 53, 2113-2121. [CrossRef] 
58. Ullman, A.M.; Liu, Y.; Huynh, M.; Bediako, D.K.; Wang, H.; Anderson, B.L.; Powers, D.C.; Breen, J.J.; Abruna, H.D.; Nocera, D.G. Water Oxidation Catalysis by Co(II) Impurities in $\mathrm{Co}_{4}{ }_{4} \mathrm{O}_{4}$ Cubanes. J. Am. Chem. Soc. 2014, 136, 17681-17688. [CrossRef]

59. Song, F.Y.; More, R.; Schilling, M.; Smolentsev, G.; Azzaroli, N.; Fox, T.; Luber, S.; Patzke, G.R. $\left\{\mathrm{Co}_{4} \mathrm{O}_{4}\right\}$ and $\left\{\mathrm{Co}_{x} \mathrm{Ni}_{4-\mathrm{x}} \mathrm{O}_{4}\right\}$ Cubane Water Oxidation Catalysts as Surface Cut-Outs of Cobalt Oxides. J. Am. Chem. Soc. 2017, 139, 14198-14208. [CrossRef]

60. Evangelisti, F.; More, R.; Hodel, F.; Luber, S.; Patzke, G.R. 3d-4f $\left\{\mathrm{Co}_{3}{ }_{3} \mathrm{Ln}(\mathrm{OR})_{4}\right\}$ Cubanes as Bio-lnspired Water Oxidation Catalysts. J. Am. Chem. Soc. 2015, 137, 11076-11084. [CrossRef]

61. Zhou, X.; Li, F.; Li, H.; Zhang, B.; Yu, F.; Sun, L. Photocatalytic Water Oxidation by Molecular Assemblies Based on Cobalt Catalysts. ChemSusChem 2014, 7, 2453-2456. [CrossRef] [PubMed]

62. Lv, H.; Song, J.; Geletii, Y.V.; Vickers, J.W.; Sumliner, J.M.; Musaev, D.G.; Koegerler, P.; Zhuk, P.F.; Bacsa, J.; Zhu, G.; et al. An Exceptionally Fast Homogeneous Carbon-Free Cobalt-Based Water Oxidation Catalyst. J. Am. Chem. Soc. 2014, 136, 9268-9271. [CrossRef] [PubMed]

63. Xu, Q.; Li, H.; Chi, L.; Zhang, L.; Wan, Z.; Ding, Y.; Wang, J. Identification of homogeneous $\mathrm{Co}_{4}\left(\mathrm{H}_{2} \mathrm{O}\right)_{4}(\mathrm{HPMIDA})_{2}(\mathrm{PMIDA})_{2}{ }^{6-}$ as an effective molecular-light-driven water oxidation catalyst. Appl. Catal. B Environ. 2017, 202, 397-403. [CrossRef]

64. Lin, J.; Meng, X.; Zheng, M.; Ma, B.; Ding, Y. Insight into a hexanuclear cobalt complex: Strategy to construct efficient catalysts for visible light-driven water oxidation. Appl. Catal. B Environ. 2019, 241, 351-358. [CrossRef]

65. Chen, W.-C.; Wang, X.-L.; Qin, C.; Shao, K.-Z.; Su, Z.-M.; Wang, E.-B. A carbon-free polyoxometalate molecular catalyst with a cobalt-arsenic core for visible light-driven water oxidation. Chem. Commun. 2016, 52, 9514-9517. [CrossRef] [PubMed]

66. Xu, J.H.; Guo, L.-Y.; Su, H.-F.; Gao, X.; Wu, X.-F.; Wang, W.-G.; Tung, C.-H.; Sun, D. Heptanuclear Co ${ }_{5}{ }_{5} \mathrm{Co}^{\mathrm{III}}{ }_{2}$ Cluster as Efficient Water Oxidation Catalyst. Inorg. Chem. 2017, 56, 1591-1598. [CrossRef] [PubMed]

67. Wei, J.; Feng, Y.; Zhou, P.; Liu, Y.; Xu, J.; Xiang, R.; Ding, Y.; Zhao, C.; Fan, L.; Hu, C. A Bioinspired Molecular Polyoxometalate Catalyst with Two Cobalt(II) Oxide Cores for Photocatalytic Water Oxidation. ChemSusChem 2015, 8, 2630-2634. [CrossRef]

68. Natali, M.; Bazzan, I.; Goberna-Ferron, S.; Al-Oweini, R.; Ibrahim, M.; Bassil, B.S.; Dau, H.; Scandola, F.; Galan-Mascaros, J.R.; Kortz, U.; et al. Photo-assisted water oxidation by high-nuclearity cobalt-oxo cores: Tracing the catalyst fate during oxygen evolution turnover. Green Chem. 2017, 19, 2416-2426. [CrossRef]

69. Genoni, A.; La Ganga, G.; Volpe, A.; Puntoriero, F.; Di Valentin, M.; Bonchio, M.; Natali, M.; Sartorel, A. Water oxidation catalysis upon evolution of molecular Co(III) cubanes in aqueous media. Faraday Discuss. 2015, 185, 121-141. [CrossRef]

70. Costas, M. Selective C-H oxidation catalyzed by metalloporphyrins. Coord. Chem. Rev. 2011, 255, $2912-2932$. [CrossRef]

71. Barona-Castano, J.C.; Carmona-Vargas, C.C.; Brocksom, T.J.; de Oliveira, K.T. Porphyrins as Catalysts in Scalable Organic Reactions. Molecules 2016, 21, 310. [CrossRef] [PubMed]

72. Gao, W.Y.; Chrzanowski, M.; Ma, S.Q. Metal-metalloporphyrin frameworks: A resurging class of functional materials. Chem. Soc. Rev. 2014, 43, 5841-5866. [CrossRef]

73. Wang, D.; Groves, J.T. Efficient water oxidation catalyzed by homogeneous cationic cobalt porphyrins with critical roles for the buffer base. Proc. Natl. Acad. Sci. USA 2013, 110, 15579-15584. [CrossRef] [PubMed]

74. Bryliakov, K.P.; Talsi, E.P. Active sites and mechanisms of bioinspired oxidation with $\mathrm{H}_{2} \mathrm{O}_{2}$, catalyzed by non-heme Fe and related Mn complexes. Coord. Chem. Rev. 2014, 276, 73-96. [CrossRef]

75. Olivo, G.; Cusso, O.; Borrell, M.; Costas, M. Oxidation of alkane and alkene moieties with biologically inspired nonheme iron catalysts and hydrogen peroxide: From free radicals to stereoselective transformations. J. Biol. Inorg. Chem. 2017, 22, 425-452. [CrossRef] [PubMed]

76. Chakrabarty, R.; Sarmah, P.; Saha, B.; Chakravorty, S.; Das, B.K. Catalytic Properties of Cobalt(III)-Oxo Cubanes in the TBHP Oxidation of Benzylic Alcohols. Inorg. Chem. 2009, 48, 6371-6379. [CrossRef] [PubMed]

77. Wang, P.; Shannigrahi, S.; Yakovlev, N.L.; Hor, T.S.A. General One-Step Self-Assembly of Isostructural Intermetallic $\mathrm{Co}_{3}{ }_{3} \mathrm{Ln}^{\mathrm{III}}$ Cubane Aggregates. Inorg. Chem. 2012, 51, 12059-12061. [CrossRef] [PubMed] 
78. Schulze, M.; Kunz, V.; Frischmann, P.D.; Wuerthner, F. A supramolecular ruthenium macrocycle with high catalytic activity for water oxidation that mechanistically mimics photosystem II. Nat. Chem. 2016, 8, 577-584. [CrossRef]

79. Lisnard, L.; Mialane, P.; Dolbecq, A.; Marrot, J.; Clemente-Juan, J.M.; Coronado, E.; Keita, B.; de Oliveira, P.; Nadjo, L.; Secheresse, F. Effect of cyanato, azido, carboxylato, and carbonato ligands on the formation of cobalt(II) polyoxometalates: Characterization, magnetic, and electrochemical studies of multinuclear cobalt clusters. Chem. Eur. J. 2007, 13, 3525-3536. [CrossRef]

80. Galanmascaros, J.R.; Gomezgarcia, C.J.; Borrasalmenar, J.J.; Coronado, E. High-Nuclearity Magnetic Clusters-Magnetic-Properties of a 9 Cobalt Cluster Encapsulated in a Polyoxometalate, $\mathrm{Co}_{9}(\mathrm{OH})_{3}\left(\mathrm{H}_{2} \mathrm{O}\right)_{6}$ $\left(\mathrm{HPO}_{4}\right)_{2}\left(\mathrm{PW}_{9} \mathrm{O}_{34}\right)_{3}{ }^{16-}$. Adv. Mater. 1994, 6, 221-223. [CrossRef]

81. Bassil, B.S.; Nellutla, S.; Kortz, U.; Stowe, A.C.; van Tol, J.; Dalal, N.S.; Keita, B.; Nadjo, L. The satellite-shaped $\mathrm{Co}_{15}$ polyoxotungstate, $\left.\left.\mathrm{Co}_{6}\left(\mathrm{H}_{2} \mathrm{O}\right)_{30}\right\} \mathrm{Co}_{9} \mathrm{Cl}_{2}(\mathrm{OH})_{3}\left(\mathrm{H}_{2} \mathrm{O}\right)_{9}\left(\mathrm{SiW}_{8} \mathrm{O}_{31}\right)_{3}\right\}^{5-}$. Inorg. Chem. 2005, 44, 2659-2665. [CrossRef] [PubMed]

82. Ibrahim, M.; Lan, Y.H.; Bassil, B.S.; Xiang, Y.X.; Suchopar, A.; Powell, A.K.; Kortz, U. Hexadecacobalt(II)-Containing Polyoxometalate-Based Single-Molecule Magnet. Angew. Chem. Int. Ed. 2011, 50, 4708-4711. [CrossRef] [PubMed]

(C) 2018 by the authors. Licensee MDPI, Basel, Switzerland. This article is an open access article distributed under the terms and conditions of the Creative Commons Attribution (CC BY) license (http:/ / creativecommons.org/licenses/by/4.0/). 